\title{
Detailed Fluid Inclusion and Stable Isotope Analysis on Deep Carbonates from the North Alpine Foreland Basin to Constrain Paleofluid Evolution
}

\author{
Elena Mraz $\left(\mathbb{D},{ }^{1}\right.$ Markus Wolfgramm, ${ }^{2}$ Inga Moeck, ${ }^{3}$ and Kurosch Thuro ${ }^{1}$ \\ ${ }^{1}$ Technical University of Munich, Arcisstr. 21, Munich 80333, Germany \\ ${ }^{2}$ Geothermie Neubrandenburg GmbH, Seestr. 7A, Neubrandenburg 17033, Germany \\ ${ }^{3}$ Leibniz Institute for Applied Geophysics, Stilleweg 2, Hannover 30655, Germany \\ Correspondence should be addressed to Elena Mraz; e.mraz@tum.de
}

Received 29 October 2018; Revised 19 January 2019; Accepted 13 February 2019; Published 22 April 2019

Academic Editor: Paolo Fulignati

Copyright (c) 2019 Elena Mraz et al. This is an open access article distributed under the Creative Commons Attribution License, which permits unrestricted use, distribution, and reproduction in any medium, provided the original work is properly cited.

\begin{abstract}
The recent interest on environmentally friendly energy resources has increased the economic interest on the Upper Jurassic carbonate rocks in the North Alpine Foreland Basin, which serves as a hydrogeothermal reservoir. An economic reservoir use by geothermal fluid extraction and injection requires a decent understanding of porosity-permeability evolution of the deep laying Upper Jurassic strata at depths greater than $2000 \mathrm{~m}$. The analysis of paleofluids caught in cements of the rock mass helps to determine the postdepositional reservoir evolution and fluid migration. Therefore, the high- and low-permeability areas of the Upper Jurassic in the North Alpine Foreland Basin referred to as Molasse Basin were analyzed by means of encountered postdepositional cements to determine the reservoir evolution. The cements were sampled at different hydrocarbon and geothermal wells, as well as at outcrops in the Franconian and Swabian Alb. To determine the composition and temperature of the paleofluids, fluid inclusions and cements of the Upper Jurassic carbonate rocks were analyzed by microthermometry and stable isotope measurements. Since drill cuttings are a rather available sample material compared to drill cores, a new microthermometry measurement method was achieved for the around $1 \mathrm{~mm}$ drill cuttings. Salinity and formation temperature of paleofluids in fluid inclusions and isotope data are consistent with previous studies and reveal a 5-stage evolution: the main cementation phases are composed of (I) the early diagenesis in limestones (200-400 $\mathrm{m}, 40-50^{\circ} \mathrm{C}$ ), (II) early diagenetic dolomitization, and (III) burial dolomitization (1-2 km, II: $40-90^{\circ} \mathrm{C}$; III: $70-100^{\circ} \mathrm{C} ; 40 \mathrm{~g} / \mathrm{L} \mathrm{NaCl}$ equiv.), and (IV) late burial calcification (IIIa: $110-140^{\circ} \mathrm{C}$, IIIb: $140-200^{\circ} \mathrm{C}$ ) linked to tectonic features in the Molasse Basin. In the outcrop samples, a subsequent $(\mathrm{V})$ cementation phase was determined controlled by karstification. In the southwest, an increase in salinity of the fluid inclusions in vein calcites, above the salinity of the Jurassic seawater, highlights the influence of basin fluids (diagenetic, evaporitic). In the other eastern wells, vein calcites have precipitated from a low saline fluid of around $10-20 \mathrm{~g} / \mathrm{L} \mathrm{NaCl}$ equiv. The low salinity and the isotope values support the theory of a continuous influence of descending meteoric fluids. Consequently, the Upper Jurassic seawater has been diluted by a meteoric fluid to a low saline fluid $(<1 \mathrm{~g} / \mathrm{L})$, especially in areas with high permeability. Here, we show how a better understanding of cementation trajectory at depth can help to generate a better understanding of geothermal usability in deep carbonate reservoirs.
\end{abstract}

\section{Introduction}

Processes which influence the porosity and permeability of a potential reservoir can be characterized when we know the diagenetic history. During the 1960-80s, the North Alpine Foreland Basin was explored for oil and gas, which were found primarily in Cenozoic sandstones, and to a minor degree in Upper Jurassic carbonate rocks [1-5]. Previous studies focused on the maturation of organic matter in the Cenozoic sedimentary rocks and to a minor degree on the burial history and paleogeothermal gradient of the Mesozoic strata [6-10]. Our knowledge of the burial history, the paleogeothermal regime, and the processes which control the Upper Jurassic reservoir is therefore quite incomplete. 
However, for the North Alpine Foreland Basin, the so-called Molasse Basin, the following basin developments have been described in previous studies.

The geothermal use of the Upper Jurassic reservoir in the Molasse Basin and the stored water has been of special interest since 1980s [11-13]. Previous researchers described the origin of the present reservoir water to be Pleistocene meteoric waters $[11,14-16]$, which have migrated into the deep Upper Jurassic aquifer. Thereby, the former saline seawater became diluted and less saline. Studies about the dilution and fluid development, however, were conducted by Reinhold [17], Liedmann [18], Prestel et al. [19], and Bertleff [20] for the shallow Upper Jurassic and for outcrops of the Swabian and Franconian Alb in the north. In general, the diagenetic development of temperatures and pressures and, e.g., dolomitization, has been successfully described for the shallow Upper Jurassic strata with maximum depths of $1200 \mathrm{~m}$ $[12,17,18]$, but they have not been determined for the deeper aquifer $(>1.000 \mathrm{~m})$, which is used for geothermal energy production today.

The main aim of this paper is to reconstruct the paleofluid and paleotemperature evolution of the Upper Jurassic reservoir. As physical and chemical conditions of diagenetic processes are preserved in fluid inclusions and cement phases, the focus of this study is on the fluid evolution stored in different cement phases of the carbonate rocks. The fluid inclusions and cement phases from geothermal wells and hydrocarbon boreholes of the Upper Jurassic reservoir were measured to increase the study area and knowledge to greater depths (up to $4,500 \mathrm{~m}$ ). The fluid composition and paleotemperatures were analyzed using microthermometry and calculated from stable isotope data, which were then employed to reconstruct the Upper Jurassic reservoir evolution. In addition, the lithology of the carbonate rocks was characterized [21]. As only drill cuttings were produced from most geothermal wells, the rock samples of those wells were only subdivided into limestone, dolostone, dolomitic limestone, and vein calcites. Diagenesis, as well as dolomitization, is still the focus of research but could not be investigated in detail in this study. In the present study, we were further able to understand the occurrence of temperature anomalies by looking at the evolution of the fluids, compositions, and temperatures.

\section{Study Area and Sample Points}

Rock samples, drill cores, and cuttings were available from 13 wells (252 samples) in the southern Molasse Basin (Table 1, Figure 1). The wells are St. Gallen (STG), hydrocarbon well A1, hydrocarbon well C1, Bad Woerishofen (BWO), Schongau (SCH), Geretsried (GEN-1 and GEN-1ST-A1), Unterhaching (UHA1 and UHA2), Taufkirchen (TFK), Sauerlach (SAU), Kirchstockach (KIR), Traunreut (TRN), Freiham (FRH), and Moosburg (MOS). The sediment thickness of the Upper Jurassic carbonate rocks varies around $400-600 \mathrm{~m}$ in the study area. Most carbonate rock samples (limestones and dolostones) of this study belong to the middle to upper Kimmeridgian (previously Malm Delta-Epsilon). The Kimmeridgian rocks represent the part of the Upper Jurassic aquifer, which is mainly dolomitized and highly permeable. The samples and/or core material often consisted of transparent euhedral calcite crystals of veins associated with sucrosic dolomite crystals (planar-e dolostone; upper part of the Upper Jurassic). In some samples, almost white vein calcites were observed (lower part of the Upper Jurassic) together with gray to dark micritic limestones or strongly toothed massive dolostones (planar-a dolostone).

Furthermore, rock samples from 21 outcrops (74 samples) originating from the Franconian Alb and Swabian Alb (Figure 1) were analyzed. The outcrop samples are carbonate rocks, generally of the Kimmeridgian, and can show dedolomitization and karst phenomena due to the comparable longer surface influences. Drill cutting samples ranging from limestones, dolostone, and vein calcite crystals as well as dedolomite were used for the isotope measurements in this study (Table 1). The reddish to brown but usually white calcite and dedolomite samples were limited to surface outcrops (karst zones). For the microthermometry measurements, we mainly analyzed fluid inclusions in vein calcite and in planar-e dolostone, which were linked to fracture zones. There was further a hydrocarbon migration, visible by bitumen impregnation, in the Upper Jurassic rocks, which was described and analyzed but not used in this study. The focus of this study was on the deep, down-lifted carbonatic Upper Jurassic reservoir $(>1,000 \mathrm{~m})$ in the Molasse Basin (Figure 2). The Upper Jurassic reservoir was sampled over a wide depth range (0-4722 $\mathrm{m}$ TVD) to determine possible changes in the fluid composition and temperature with increasing depth.

\section{Geology and Petrography}

During the Late Jurassic, the passive Tethys margin was occupied by an extensive carbonate-dominated platform that extended northward, the so-called Franconian platform [22]. In the late Kimmeridgian to Tithonian, the sea level gradually dropped and a sea level low stand was reached at the JurassicCretaceous transition [22]. The Tethys transgressed and regressed from the south on the platform during the Cretaceous, causing erosional phases of the Upper Jurassic rocks. In the Paleogene, the Central European Alps developed as the Adriatic and European plates collided [23], which caused a southwards subduction of the Penninic Ocean. This convergence resulted in a northward thrusting of the European passive margin and a downward flexing of the European plate. This entailed the formation of the North Alpine Foreland Basin (Molasse Basin) [24]. The subsequent deposition of two regressive cycles of marine water and freshwater sediments occurred during the Paleogene [23, 25]. Afterward, Quaternary sediments were deposited on top (Figure 2). The Molasse Basin can be subdivided into a western and an eastern part with the transition zone west of Munich according to the investigated well data.

The evolution of the Upper Jurassic reservoir in the Molasse Basin started with the deposition of carbonate rocks, limestones, and dolostones on a carbonate platform in an epicontinental sea (Figure 3) [26, 27]. The lithology, stratigraphy, and microfacies of the Upper Jurassic carbonate rocks of the Molasse Basin are further described in detail in Mraz 
TABLE 1: Overview of the sampled wells and outcrops for the reconstruction of paleofluid composition and temperature in the Molasse Basin (Figure 1).

\begin{tabular}{|c|c|c|c|c|c|c|c|c|}
\hline \multirow{2}{*}{ Well } & \multirow{2}{*}{ Depth (m TVD) } & \multirow{2}{*}{ Stratigraphy, sample } & \multicolumn{3}{|c|}{ Fluid inclusions } & \multicolumn{3}{|c|}{ Stable isotopes } \\
\hline & & & $n$ & Thick section & Cutting sample & $n$ & Thick section & Cutting sample \\
\hline STG & $4350-4440$ & ti-kim, cc & 25 & 3 & & 15 & $\mathrm{x}$ & $\mathrm{x}$ \\
\hline A1 & $2646-2740$ & ti-kim, cc & 23 & 2 & & & & \\
\hline MOS & 1288- 1449 & ti-kim, cc, d & 43 & 2 & & 7 & $\mathrm{x}$ & \\
\hline $\mathrm{C} 1$ & 3303 & ti-kim, cc & 15 & 1 & & & & \\
\hline $\mathrm{SCH}$ & $4375-4378$ & ti-kim, cc, d & 105 & 4 & & & & \\
\hline FRH & $2130-2410$ & ti-kim, cc, d & 18 & & 5 & & & \\
\hline GEN & $4360-4850$ & ti-kim, cc, d & 113 & 2 & 7 & 20 & $\mathrm{x}$ & $\mathrm{x}$ \\
\hline UHA & $3060-3555$ & ti-kim, cc & 40 & & 2 & 59 & & $\mathrm{x}$ \\
\hline TRN & $4220-4860$ & ti-kim, cc, d & 19 & & 10 & 11 & & $\mathrm{x}$ \\
\hline BWO & $2370-2565$ & ti-kim, cc & 10 & & 5 & & & \\
\hline KIR & $3425-4090$ & ti-kim, cc & & & & 46 & & $\mathrm{x}$ \\
\hline SAU & $4060-5475$ & ti-kim, cc & & & & 41 & & $\mathrm{x}$ \\
\hline TFK & $3480-3933$ & ti-kim, cc & & & & 10 & & $\mathrm{x}$ \\
\hline \multicolumn{9}{|c|}{ Outcrop } \\
\hline 2 & & $\mathrm{ti}, \mathrm{cc}$ & & & & 2 & $\mathrm{x}$ & \\
\hline 3 & & kim, cc & & & & 1 & $\mathrm{x}$ & \\
\hline 4 & & kim, cc & & & & 2 & $\mathrm{x}$ & \\
\hline 6 & & kim, cc & 1 & 2 & & 2 & $\mathrm{x}$ & \\
\hline 7 & & kim, cc & & & & 2 & $\mathrm{x}$ & \\
\hline 10 & & kim, cc & 4 & 4 & & 14 & $\mathrm{x}$ & \\
\hline 11 & & $\mathrm{ti}, \mathrm{cc}$ & 8 & 1 & & 1 & $\mathrm{x}$ & \\
\hline 12 & & kim, cc & 4 & 1 & & & $\mathrm{x}$ & \\
\hline 13 & & kim, cc, d & 4 & 1 & & 2 & $\mathrm{x}$ & \\
\hline 14 & & kim, cc & 1 & 1 & & & $\mathrm{x}$ & \\
\hline 15 & & ti, cc & & & & 2 & $\mathrm{x}$ & \\
\hline 19 & & $\mathrm{ti}, \mathrm{cc}$ & & & & 4 & $\mathrm{x}$ & \\
\hline 21 & & kim, cc & 2 & 1 & & & & \\
\hline 25 & & kim, cc & 1 & 1 & & & & \\
\hline 26 & & kim, cc & & & & 2 & $\mathrm{x}$ & \\
\hline 27 & & kim, cc, d & 1 & 1 & & & & \\
\hline 30 & & kim, cc & & & & 2 & $\mathrm{x}$ & \\
\hline 32 & & kim, cc & 1 & 2 & & 2 & $\mathrm{x}$ & \\
\hline 34 & & kim, cc & 1 & 1 & & 2 & $\mathrm{x}$ & \\
\hline 35 & & kim, cc & & & & 2 & $\mathrm{x}$ & \\
\hline 39 & & kim, cc & 4 & 1 & & 15 & $\mathrm{x}$ & \\
\hline Sum & & & 443 & 31 & 29 & 266 & $\min .21$ & $\min .7$ \\
\hline
\end{tabular}

The thick sections were made from drill cores. n: number of measurements. Samples: calcite: cc; dolomite: d; Tithonian: ti; Kimmeridgian: kim. The well abbreviations are the same as in Figure 1.

et al. [21], (2017), Beichel et al. [28], Lüschen et al. [29], (2012), Wolfgramm et al. [30], Reinhold [17], Liedmann [18], Geyer and Gwinner [31], Meyer and Schmidt-Kaler [26], and others. A strongly simplified evolution from deposition to the recent structure of Upper Jurassic carbonate rocks is given in Figure 4. The evolution of the Upper Jurassic carbonate rocks started with the deposition of relatively pure limestones of the massive facies and with thin alternating layers of limestone, marlstone, argillaceous marlstone, and claystone of the bedded facies. The massive facies was formed during early diagenesis as a light gray to beige carbonate rocks (grainstone to bindstone), and the bedded facies as a gray to brown mostly micritic carbonate rocks (mudstonewackestone). Small dolomite crystals were formed in the vicinity of small fractures and stylolites in an early diagenetic stage. Overall, dolomite crystals were formed in three phases during the burial of the sediments according to Reinhold [17]. Faults and fractures were filled with calcite crystals during a late phase of burial, as the white and transparent calcite crystals have usually precipitated on the massive dolostones 


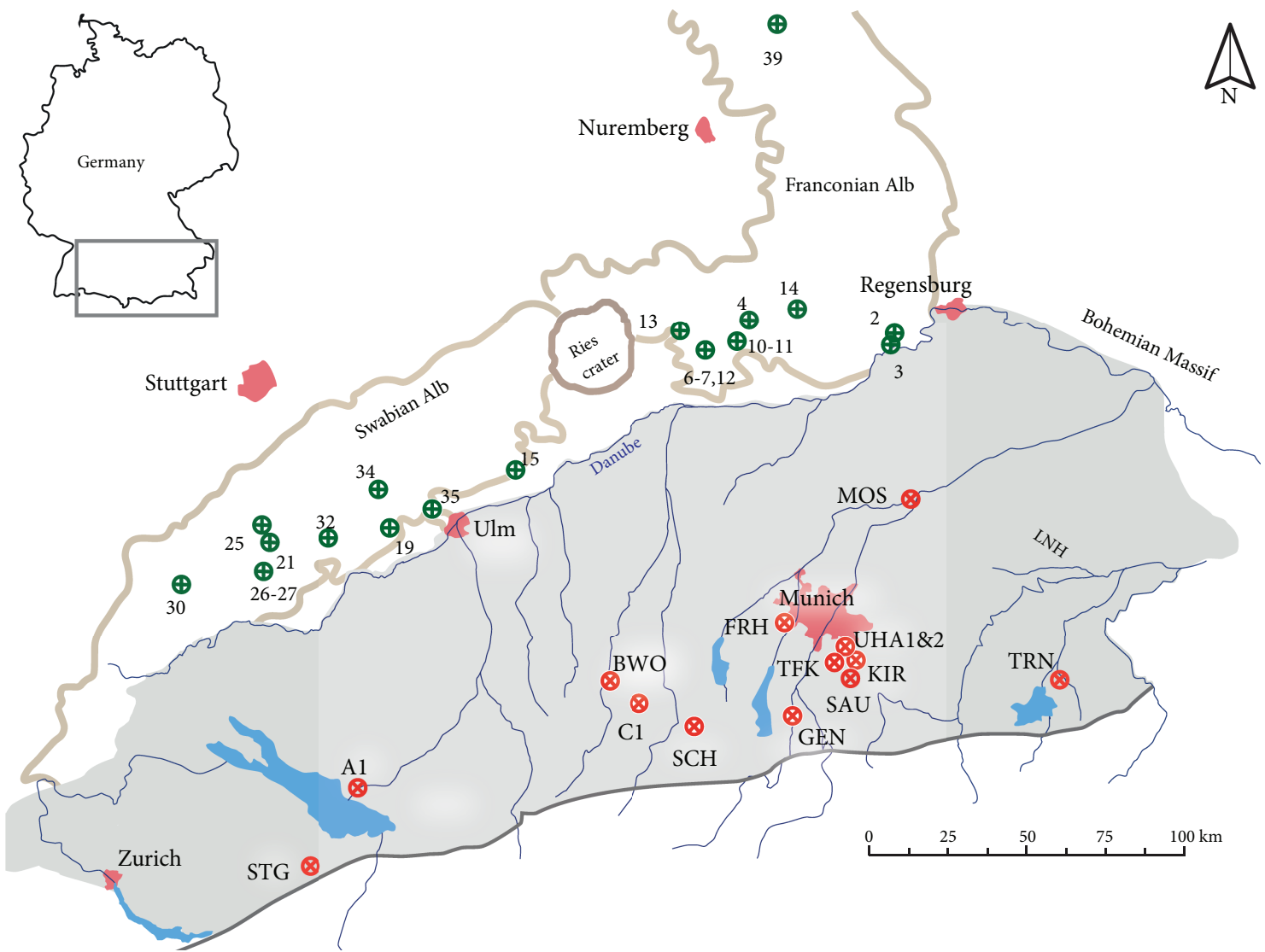

Molasse basin

(2) Deep Borehole

$\oplus$ Outcrop

FIGURE 1: Overview of the study area in the Molasse Basin, southern Germany and eastern Switzerland. FRH: Freiham; GEN: Geretsried; KIR: Kirchstockach; MOS Moosburg; SAU Sauerlach; TFK Taufkirchen; TRN: Traunreut; UHA: Unterhaching; SCH: Schongau; STG: St. Gallen; BWO: Bad Woerishofen, outcrops according to Table 1.

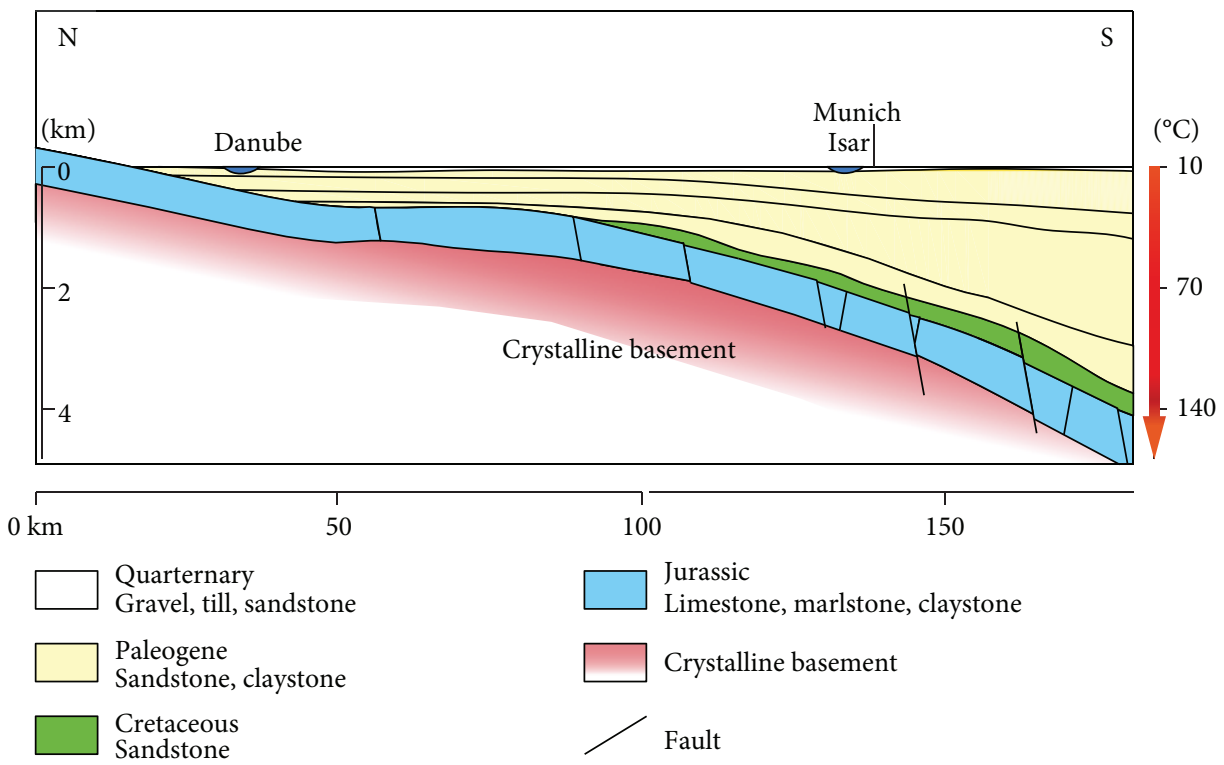

FIgURE 2: Cross section of the Molasse Basin in southern Germany. 


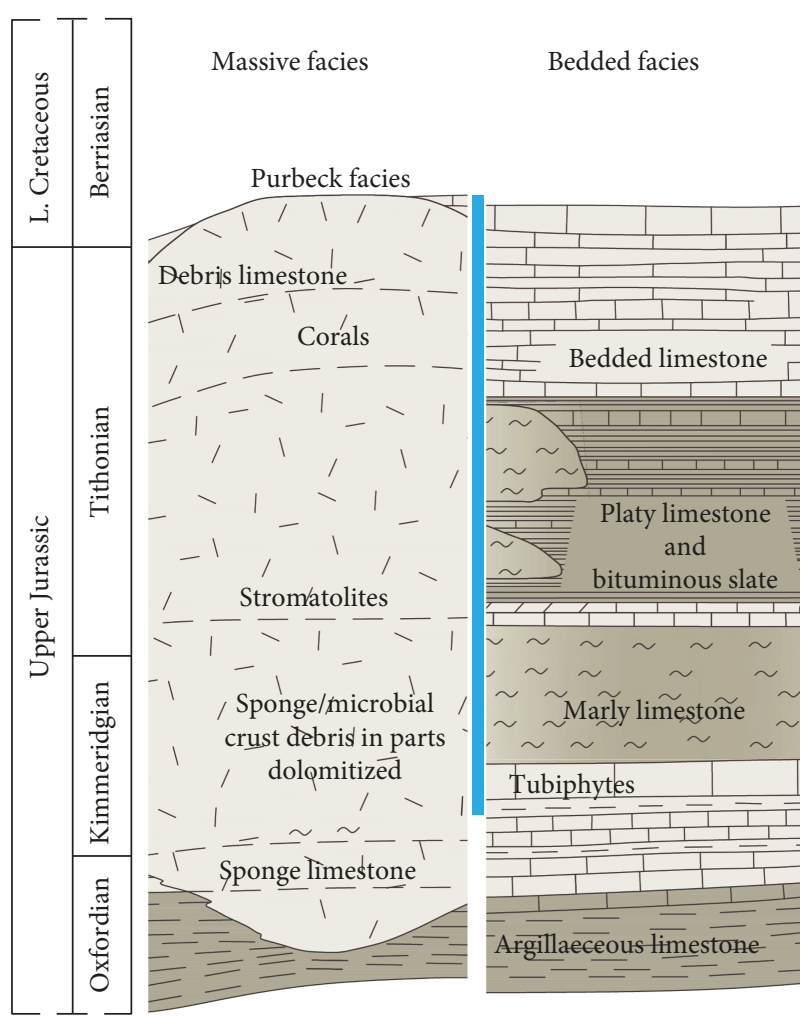

FIGURE 3: Schematic stratigraphic column of the Upper Jurassic strata in the Molasse Basin in southern Germany. The blue column shows the sample area of this study.

and limestones. Generally, two types of calcite crystals can be distinguished: firstly, transparent calcite crystals, present in the upper part of the Upper Jurassic, and secondly, white calcite crystals in darker limestones and dolostones, which are dominant in the lower part of the Upper Jurassic. In addition, a third type of calcite crystals with white and transparent crystals and red and yellow rims were identified together with dedolomite crystals. The appearance of the third type is limited to the surface outcrops of the Swabian and Franconian Alb.

The petrography of dolomite crystals depended strongly on the depositional and diagenetic fabric of the Upper Jurassic rocks, as pure carbonates showed bigger and clearer dolomite crystals than the dark carbonates did in this study. Furthermore, we described a diagenetic replacement of limestone by dolomite, so-called matrix or replacive dolomite, which is in line with previous studies [17, 18, 32]. This dolomite replacement is usually affected by temperature, alkalinity, $\mathrm{pH}$ value, concentration of $\mathrm{Mg}^{2+}$ and $\mathrm{Ca}^{2+}, \mathrm{Mg}^{2+}$ to $\mathrm{Ca}^{2+}$ ratio, fluid, rock ratio, mineralogy of the carbonate replacement, and surface area $[32,33]$. The diagenetic replacement is one of the dolomitization models, which are still being studied in focus and have not been solved for the Upper Jurassic in Germany [32, 34, 35].

\section{Methodology}

Rock samples including hand specimens, drill cores, and drill cuttings from boreholes and outcrops were used in this study to determine the lithology and diagenesis. The thin and thick sections were made from drill core and hand specimens. The drill cutting material was made into thin sections with bluedyed resin. The stable isotopes $\delta^{18} \mathrm{O}$ and $\delta^{13} \mathrm{C}$ were measured from drill cuttings. For the microthermometry measurements, a new sample approach with cuttings of around $1 \mathrm{~mm}$ was developed by using the unprepared and unpolished drill cuttings (Figure 5). In addition, conventional thick sections were measured with microthermometry. At the Geretsried well, drill cuttings and conventional double-side polished thick sections of bore cores were measured using microthermometry to compare the results and confirm the drill cutting measurements. To measure drill cuttings using microthermometry, the drill cuttings are usually embedded in an epoxy resin, polished on both sides, and used as thick sections with the drill cuttings still embedded in the resin. However, the epoxy resin is not stable in the temperature range between $-110^{\circ} \mathrm{C}$ and $200^{\circ} \mathrm{C}$, which was necessary for this study. Silicone and Teflon are stable polymers for this temperature range, but they are soft at room temperature, and the cuttings lose their bond to the polymers during polishing and fall off the resin. As a consequence, the cuttings in this study were cleaned with water and measured in the form in which they were produced. In addition, the Upper Jurassic carbonate rocks were classified by microfacies and lithology, which was published in detail by Mraz et al. [21]. The microthermometry samples of this study mainly consisted of relatively late diagenetic blocky vein calcite crystals, which precipitated along fractures or veins $[17,36]$, and to a minor degree of dolomite crystals.

For the stable isotope measurements, vein calcite crystals, limestones, dolostones, dedolomite (calcite) (Figure 5), and scales, which are calcite crystals from the geothermal power plants Unterhaching and Kirchstockach, were investigated. These samples were finely ground and examined in line with Hoefs [37] in the mass spectrometer at the University of Kiel. Approximately $10 \mathrm{mg}$ of a sample was dissolved in pure phosphoric acid. The calcite samples were completely dissolved after $4 \mathrm{~min}$, the dolomite samples after $18 \mathrm{~min}$. Subsequently, the resulting $\mathrm{CO}_{2}$ was measured at temperatures between 850 and $1000^{\circ} \mathrm{C}$ under vacuum. The ${ }^{12} \mathrm{C} /{ }^{13} \mathrm{C}$ ratios were specified in $\delta$ notation with reference to the international standard PDB, and the measurement error of the double determination was $\pm 0.5 \%$. The oxygen isotopes were given in accordance with the SMOW (water) or PDB (minerals) standard.

The microthermometry study of fluid inclusions was performed on double-polished thick sections from drill cores as well as on drill cuttings of vein calcites and dolomite crystals. The drill cuttings generally showed a smooth surface at former cleavage planes or at fresh fracture surfaces. However, not every cutting sample showed good visibility and a flat surface, and therefore they could not be measured in this fluid inclusion study. In the heating-freezing stage, the cuttings were always placed with the flat and largest surface on the silver block, and they were measured at very slow heating and cooling rates to prevent a high-temperature gradient in the sample to determine the exact temperature. Furthermore, the drill cuttings were directly measured at least 2-3 times to 


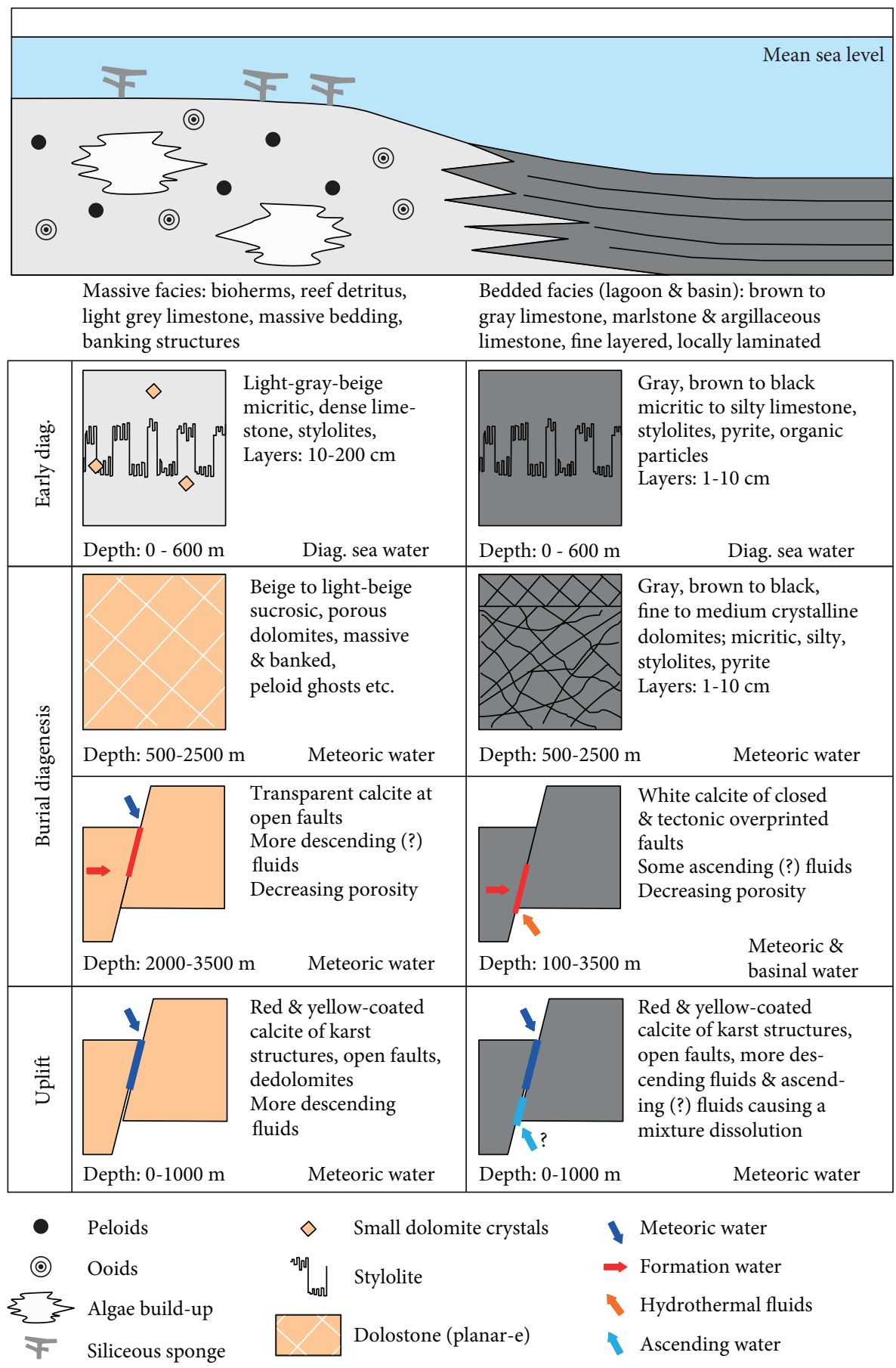

FIgURE 4: Schematic burial history of Upper Jurassic carbonates of the Molasse Basin $[17,18]$.

exclude a high-temperature gradient in the sample. The microthermometry measurements were performed on a heating-cooling stage, using a Linkam stage apparatus mounted on an Olympus microscope with a precision of $0.1 \mathrm{~K}$. For the aqueous one-phase and two-phase fluid inclusions (liquid and vapor), the shape, size, texture, genesis, phase type, host mineral, and phase volume ratio were documented in line with Van den Kerkhof and Hein [38]. When a nucleation of a bubble was not possible in one-phase fluid inclusions at around $4^{\circ} \mathrm{C}$, the sample was then further cooled to $-110^{\circ} \mathrm{C}$ to check for possible phase transitions. In contrast, two-phase fluid inclusions were first heated in increasing order to homogenization in the liquid phase and afterward cooled to $-110^{\circ} \mathrm{C}$ to minimize the possibility of inclusion deformation. The homogenization temperature $\left(T_{\mathrm{h}}\right)$ was measured in small inclusions by temperature cycling. Afterward, the eutectic temperature $\left(T_{\mathrm{e}}\right)$ and last melting and/or ice melting $\left(T_{\mathrm{m}}\right)$ temperature were measured. If possible, 

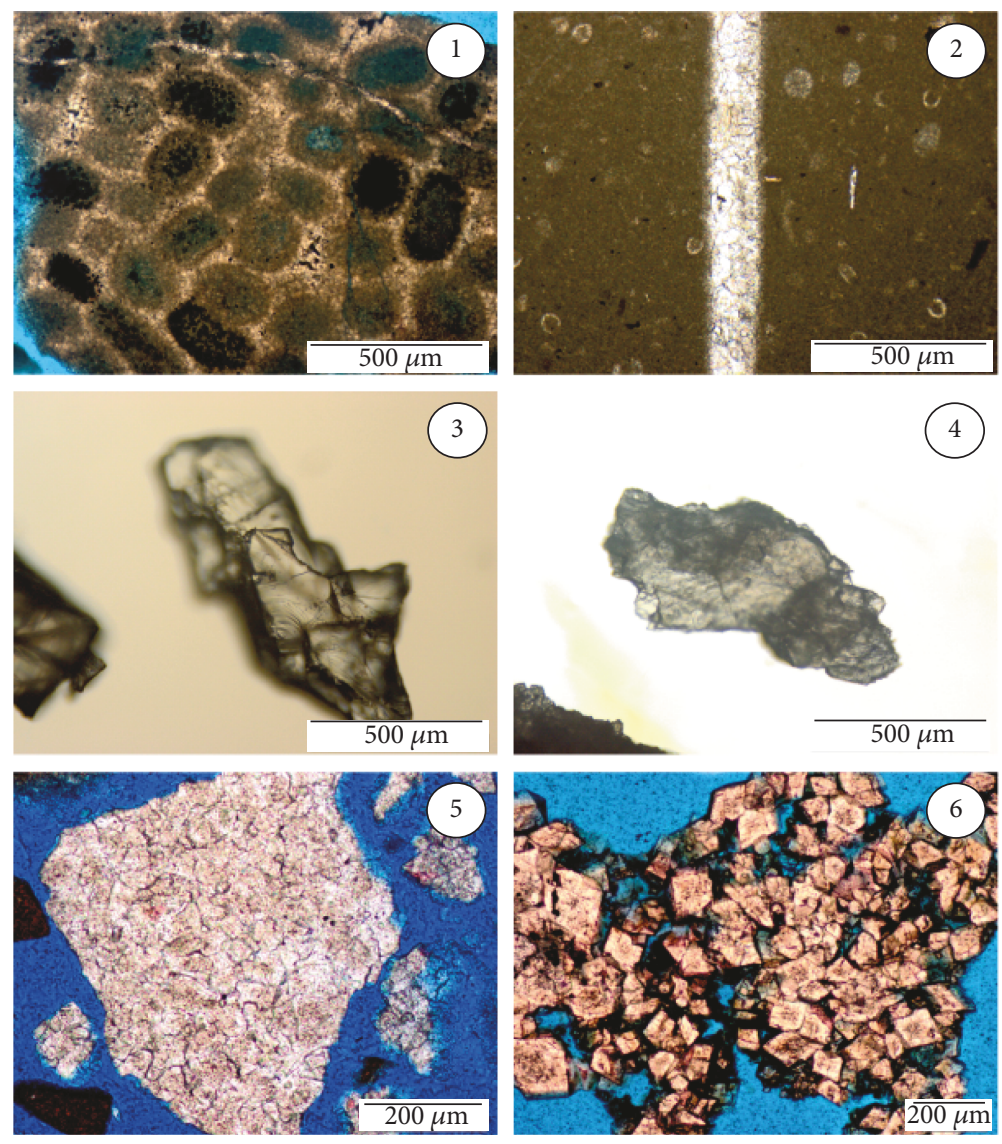

FIGURE 5: Overview of the facies types: (1) gray to beige limestone (massive facies), (2) brown limestone (bedded facies), (3) transparent vein calcite, (4) white vein calcite, (5) beige interlocked dolostone, and (6) beige sugar-grained dolostone.

fluid inclusions in an assemblage (FIA) were investigated. In the present study, data from fluid inclusion assemblages (FIA) were used preferentially before single fluid inclusion measurements. However, when a constant liquid-vapor ratio in comparison to the FIA was given, some single $T_{\mathrm{h}}$ measurements of one- and two-phase fluid inclusions were used in this study. Leakage of a fluid inclusion was sometimes not observable, but it was determined by an increase in $T_{\mathrm{m}}$ and gas bubble size during the measurement.

Sometimes, a positive $T_{\mathrm{m}}$ and a changing $T_{\mathrm{m}}$ were observed in small fluid inclusions where a liquid, vapor, and ice phase was present at $T_{\mathrm{m}}$, which can be caused by metastability or by clathrate melting. The measured positive $T_{\mathrm{m}}$ and the presence of hydrocarbons in the samples led us to assume that gases and clathrates are present. To identify the aqueous fluid system and mineral phases, micro-Raman spectroscopy was performed, using a Horiba Jobin Yvon XploRA PLUS confocal Raman microscope. The spectrometer was equipped with a frequency-doubled Nd:YAG laser $(532 \mathrm{~nm}$, with a maximum power of $22.5 \mathrm{~mW}$ ) and an Olympus 100x long working distance objective with a numerical aperture of 0.9 . The operation conditions had a confocal hole of 300 , a spectral slit of 100 , and a grating of $1800 \mathrm{~T}$. However, the high fluorescence of the calcite host mineral in the range of $2500-4000 \mathrm{~cm}^{-1}$ led to an insufficient spectrum. Consequently, the aqueous 2-phase fluid inclusions could not be specifically identified using the micro-Raman spectroscopy. In addition, no hydrocarbons were visible under UV light in the fluid inclusions.

With $T_{\mathrm{m}}$, the bulk salinity was interpreted using the computer program SoWat (sodium chloride water), which is a model of almost equation of state for fluid inclusions in the $\mathrm{H}_{2} \mathrm{O}-\mathrm{NaCl}$ system [39-41]. The measured $T_{\mathrm{h}}$ using microthermometry should represent the minimal formation or trapping temperatures of the fluid inclusions [42]. No age measurements were conducted at the different cement phases.

Up to now, no burial history with fluid and temperature data has been described for the German Molasse Basin. From the burial data of ten investigated deep boreholes, it was assumed that the maximum burial depth has been reached today. For the burial history and plot, compaction was not calculated due to a lack of data, and periods of subaerial exposure were used according to literature studies. The stratigraphy is based on two borehole profiles of this study, one in the southeastern and the other in the southwestern Molasse Basin. The eroded strata in the Upper Miocene (Upper Freshwater Molasse) were around $200 \mathrm{~m}$ thick [25, 43], the Upper Oligocene to Lower Miocene strata were around $250 \mathrm{~m}$ thick $[23,25]$, and the Cretaceous and Upper Jurassic strata were assumed to be around $600 \mathrm{~m}$ thick [44].

In the Cenozoic sedimentary rocks in the Molasse Basin, vitrinite reflectance was used to determine the thermal maturity of sediments and to reconstruct the thermal history during the Cenozoic $[6,8,45]$, but not for the Mesozoic. In 


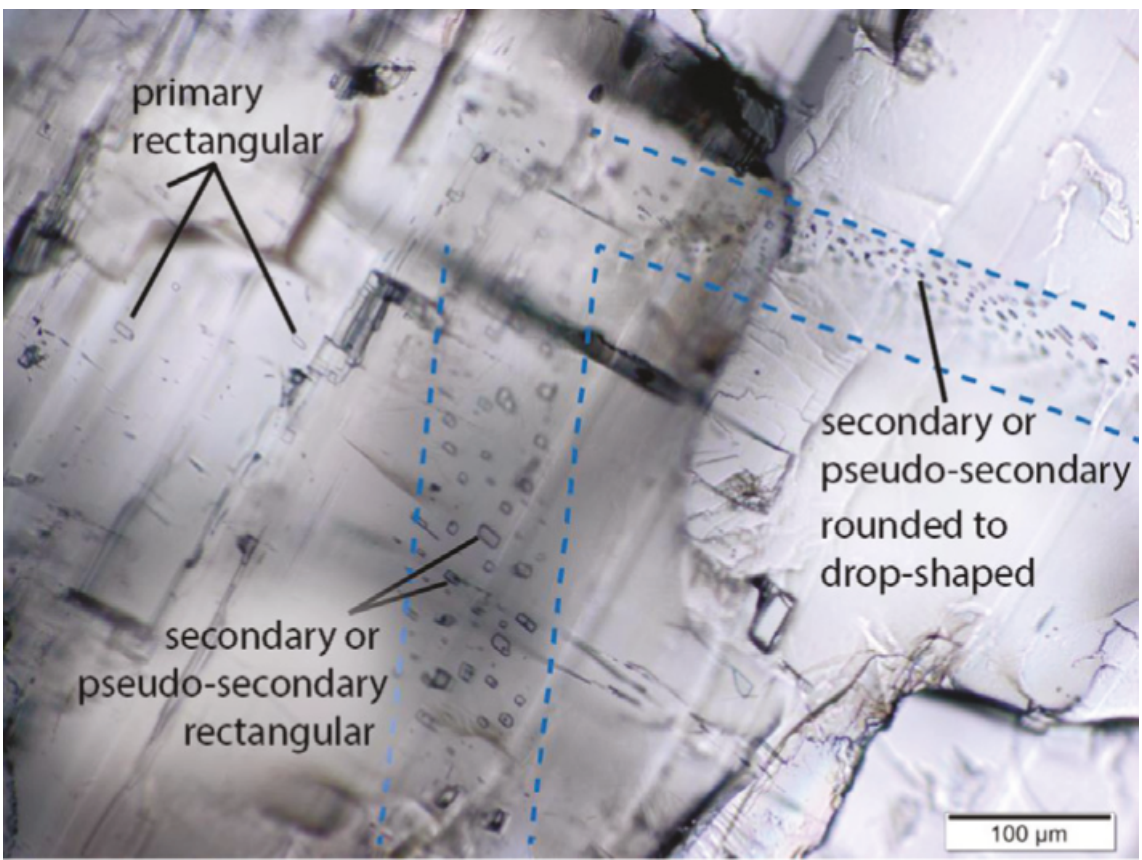

FIGURE 6: Fluid inclusion morphology in vein calcite crystals in one focal layer.

addition, vitrinite reflectance was not calibrated with fluid inclusion microthermometry in the Molasse Basin [46]. In southern Germany, contrary to other hydrocarbon exploration areas [47-52], fluid inclusions were so far not used to understand hydrocarbon migration and to reconstruct the thermal and burial history.

\section{Results}

5.1. Types of Fluid Inclusion. All measured calcite crystals, limestone cements, and vein calcite cements were completely transparent or had cloudy areas due to numerous very small inclusions $(<3.0 \mu \mathrm{m})$ (Figure 5 and Figure 6), which we were unable to measure. The dolomite crystals were idiomorphic and transparent to light beige, and FIA were only able to measure at the Traunreut and Geretsried wells. No fluid inclusion measurements could be performed in the matrix of the limestones and dolostones. The crystal size of the calcite and dolomite crystals was around $0.5 \mathrm{~mm}$ to $1.0 \mathrm{~mm}$. Overall, the size of the fluid inclusions was very small in the range from $1.2 \mu \mathrm{m}$ up to $72.0 \mu \mathrm{m}$, with the mean value of $8.2 \mu \mathrm{m}$ measured at 363 inclusions. The measured fluid inclusions were either arranged in planes or as isolated inclusions and were defined as primary, secondary, or pseudosecondary in this study. Moreover, the measured fluid inclusions were hosted in vein calcite cements and in planar-e dolostones (vein dolomite). In this study, only 17 dolomite samples with visible fluid inclusions $(\sim 3 \mu \mathrm{m})$ were found, with seven repeatedly measurable fluid inclusions $(n=21)$ and with around 20 empty fluid inclusions. Usually, primary fluid inclusions had a rectangular shape, whereas secondary or pseudo-secondary inclusions were often rounded to drop-shaped (Figure 6). The primary fluid inclusions were between 1.3 and $72.0 \mu \mathrm{m}$ (mean value $9.4 \mu \mathrm{m}, n=240$ ) and were always bigger than the secondary or pseudo-secondary fluid inclusions $(1.2-39.7 \mu \mathrm{m}$, mean value $8.3 \mu \mathrm{m}, n=109)$. Furthermore, all measured inclusions contained aqueous one-phase and 2-phase fluid inclusions. The one-phase inclusions were hosted in limestone cements, some dolomite crystals and in a few vein calcite cements, and were measured with microthermometry to describe a possible phase transition. However, most one-phase fluid inclusions showed no phase change during heating and cooling $\left(-110^{\circ} \mathrm{C}\right.$ to $+190^{\circ} \mathrm{C}$ ). All measured fluid inclusion assemblages (FIA) were homogenous, with constant liquid-vapor ratios of around $15 \%$, and showed consistent $T_{\mathrm{h}}$ and had slightly varied sizes. Because of the constant fluid-vapor ratio and similar fluid system, the fluid inclusion measurements could be compared between the investigated wells.

The thick sections and cutting samples of the Geretsried well showed similar and consistent fluid inclusion data, especially the measured $T_{\mathrm{h}}$ in FIA (cuttings: $145^{\circ} \mathrm{C}$; thick sections: $143^{\circ} \mathrm{C}$ ), which was not expected as temperature increases at the drill bit during the drilling process.

Some fluid inclusions had a $T_{\mathrm{e}}$ of $-21.6^{\circ} \mathrm{C}(n=30)$; therefore, a $\mathrm{NaCl}$ system was assumed for all evaluated samples [50].

5.2. Fluid Inclusion Temperature. The $T_{\mathrm{h}}$ for all primary fluid inclusions ranged between $59^{\circ} \mathrm{C}$ and $190^{\circ} \mathrm{C}$, with the mean value of $136^{\circ} \mathrm{C}(n=196)$ and for secondary or pseudosecondary fluid inclusions between $100^{\circ} \mathrm{C}$ and $167^{\circ} \mathrm{C}$, with the mean value of $139^{\circ} \mathrm{C}(n=94)$ (Figure 7$)$. The $T_{\mathrm{h}}$ of the secondary or pseudo-secondary fluid inclusions were nearly consistent with the primary fluid inclusions.

The fluid inclusion $T_{\mathrm{h}}$ was plotted versus sample depth of the wells in Figure 8. With increasing depth, $T_{\mathrm{h}}$ increases, but with a different gradient at the different wells. In comparison to the outcrop samples, the well samples showed an increase in $T_{\mathrm{h}}$, but consistent $T_{\mathrm{m}}$. At the Traunreut well, the recent 


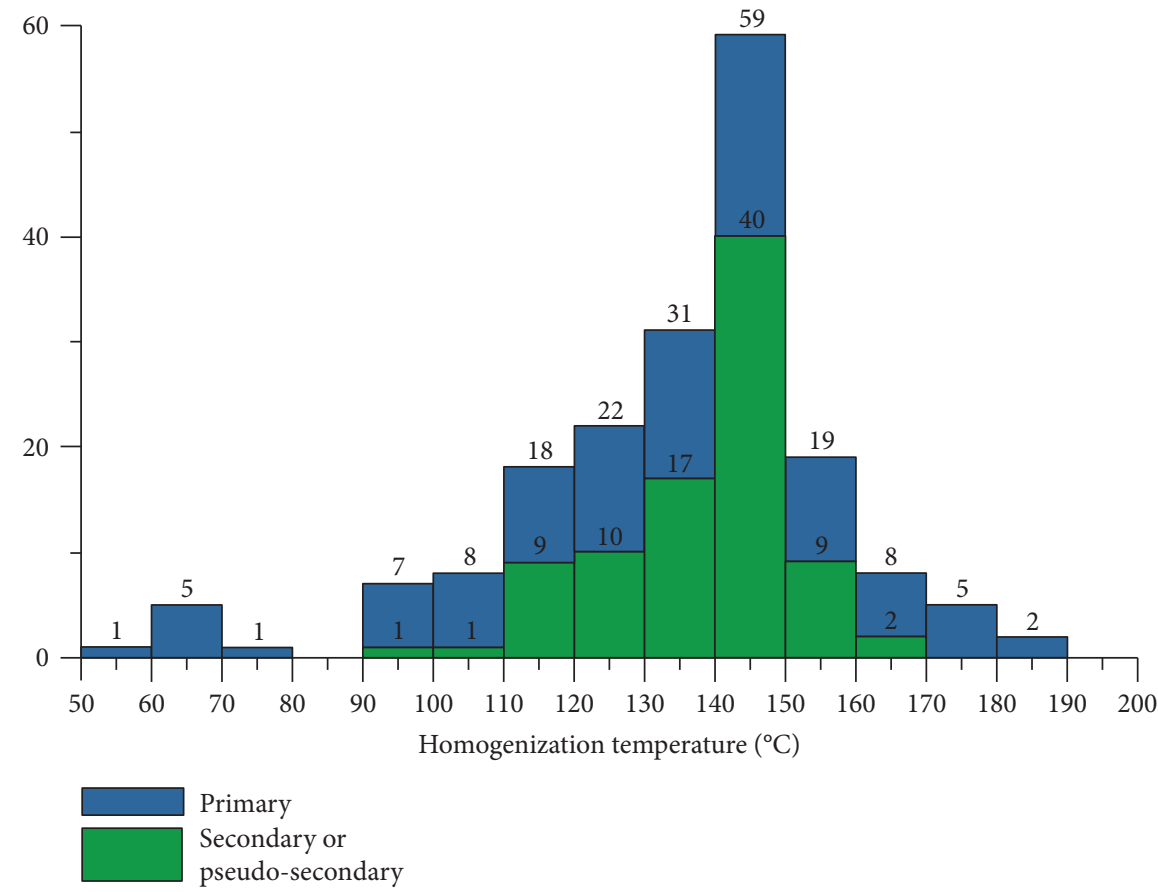

FIGURE 7: Histogram of the distribution of homogenization temperature $\left(T_{\mathrm{h}}\right)$ measured in primary, secondary, or pseudo-secondary fluid inclusions in calcite cements linked to fractures and dolostone crystals.

reservoir temperatures and $T_{\mathrm{h}}$ increased with a slightly lower gradient $(25 \mathrm{~K} / \mathrm{km})$ in comparison to the recent reservoir gradient of around $30 \mathrm{~K} / \mathrm{km}$ in the Upper Jurassic aquifer in the Munich area [53]. At the Moosburg and Freiham wells, a $T_{\mathrm{h}}$ higher than the geothermal gradient of $30 \mathrm{~K} / \mathrm{km}$ was measured (Figure 8).

$T_{\mathrm{m}}$ ranged from -31.4 to $0.0{ }^{\circ} \mathrm{C}$, with the mean value around $-1.0^{\circ} \mathrm{C}$ (Figure 9). The primary fluid inclusions had a $T_{\mathrm{m}}$ between $-31.4^{\circ} \mathrm{C}$ and $0.0^{\circ} \mathrm{C}$ with a mean value of $-2.3^{\circ} \mathrm{C}(n=143)$. In contrast, the temperature of secondary or pseudo-secondary fluid inclusions ranged between $-4.2^{\circ} \mathrm{C}$ and $-0.2^{\circ} \mathrm{C}$, with a mean value at $-1.1^{\circ} \mathrm{C}(n=49)$. There was a temperature increase in $T_{\mathrm{m}}$ from the primary fluid inclusions to the secondary or pseudo-secondary inclusions from $-2.3^{\circ} \mathrm{C}$ to $-1.1^{\circ} \mathrm{C}$, indicating decreasing salinity. In a few samples, $T_{\mathrm{m}}$ was positive with a mean value above $0^{\circ} \mathrm{C}(n=56$, min. $\left.0.1^{\circ} \mathrm{C}, \max .11 .8^{\circ} \mathrm{C}\right)$. The positive $T_{\mathrm{m}}$ changed with every heating measurement in the single fluid inclusion of an assemblage and did not stay constant. Those positive temperature measurements were not used for the further calculation and analysis. All vein calcite cements had a maximum $T_{\mathrm{m}}$ around $-1.0^{\circ} \mathrm{C}$ for primary fluid inclusions and around $-0.7^{\circ} \mathrm{C}$ for secondary or pseudo-secondary fluid inclusions. Consequently, the fluid inclusion generations can be grouped according to their salinity, but not by their $T_{\mathrm{h}}$. Some samples from hydrocarbon well A1 showed $T_{\mathrm{m}}$ below $-2.0^{\circ} \mathrm{C}$ to as low as $-18.0^{\circ} \mathrm{C}$, which results in highly saline fluids during basin evolution. The STG samples showed a slight decrease in $T_{\mathrm{m}}$ with depth, from a mean value of $-1.6^{\circ} \mathrm{C}$ at $3911 \mathrm{~m}$ and $4135 \mathrm{~m}$ to $-2.0^{\circ} \mathrm{C}$ at $4157 \mathrm{~m}$. $T_{\mathrm{m}}$ determined for dolomite crystals from the Traunreut well were around $-3.0^{\circ} \mathrm{C}$, slightly lower than the blocky, vein calcite $\left(-0.7^{\circ} \mathrm{C}\right.$ to $\left.-2.0^{\circ} \mathrm{C}\right)$. Two different generations of 2 -phase fluid inclusions could be distinguished at the GEN well, with unequal $T_{\mathrm{m}}$ and $T_{\mathrm{h}}$. The primary inclusions had a mean $T_{\mathrm{h}}$ of around $145^{\circ} \mathrm{C}$, and the mean value of the $T_{\mathrm{m}}$ was $-2^{\circ} \mathrm{C}$ for the GEN samples. ?Furthermore, the secondary or pseudo-secondary inclusions showed slightly lower $T_{\mathrm{h}}$ of around $140^{\circ} \mathrm{C}$, as well as higher and lower $T_{\mathrm{m}}$, with mean temperatures of $-0.7^{\circ} \mathrm{C}$ and $-4.0^{\circ} \mathrm{C}$ compared to the primary fluid inclusions. Hence, two secondary or pseudo-secondary fluid inclusion generations might exist at GEN, with the same $T_{\mathrm{h}}$ but different salinities.

5.3. Diagenetic Fluid Composition by Stable Isotopes. The stable isotopes $\left(\delta^{18} \mathrm{O}\right.$ and $\left.\delta^{13} \mathrm{C}\right)$ of Upper Jurassic limestones, dolostones, and calcite cements were measured from outcrop samples (Figure 10) and the deep well (Figure 11). A summary of the data is given in Table 2. In Figures 10 and 11, we distinguished between rather brown and dark gray micritic limestones and beige micritic limestones. The dark brown limestones had the highest $\delta^{18} \mathrm{O}$ value with $-3.4 \%$ PDB (Figure 11), the gray micritic limestones had an intermediate value, and the lowest $\delta^{18} \mathrm{O}$ value of $-5.4 \%$ PDB was measured in the light beige micritic limestones. This decrease in $\delta^{18} \mathrm{O}$ was caused by a meteoric water influence in the beige micritic limestones. In general, the $\delta^{13} \mathrm{C}$ of the limestones decreased from $+2.0 \%$ oDB to $+1.4 \%$ o PD (Figure 11 ) with increasing temperature during burial and $\mathrm{CO}_{2}$ degassing. The dolostones had lower $\delta^{18} \mathrm{O}$ values than the limestones and showed the same decrease in $\delta^{18} \mathrm{O}$ value as the limestones with a lighter rock color. The $\delta^{18} \mathrm{O}$ value decreased from the dark-brown platy dolomite crystals (-4.5\% PDB), the lower part of the Upper Jurassic, towards the massive dolostone to the sucrosic, light-beige, secondary dolostones $\left(-7.5 \%\right.$ PDB) (Figure 11). For the dolostones, $\delta^{18} \mathrm{O}$ increased 

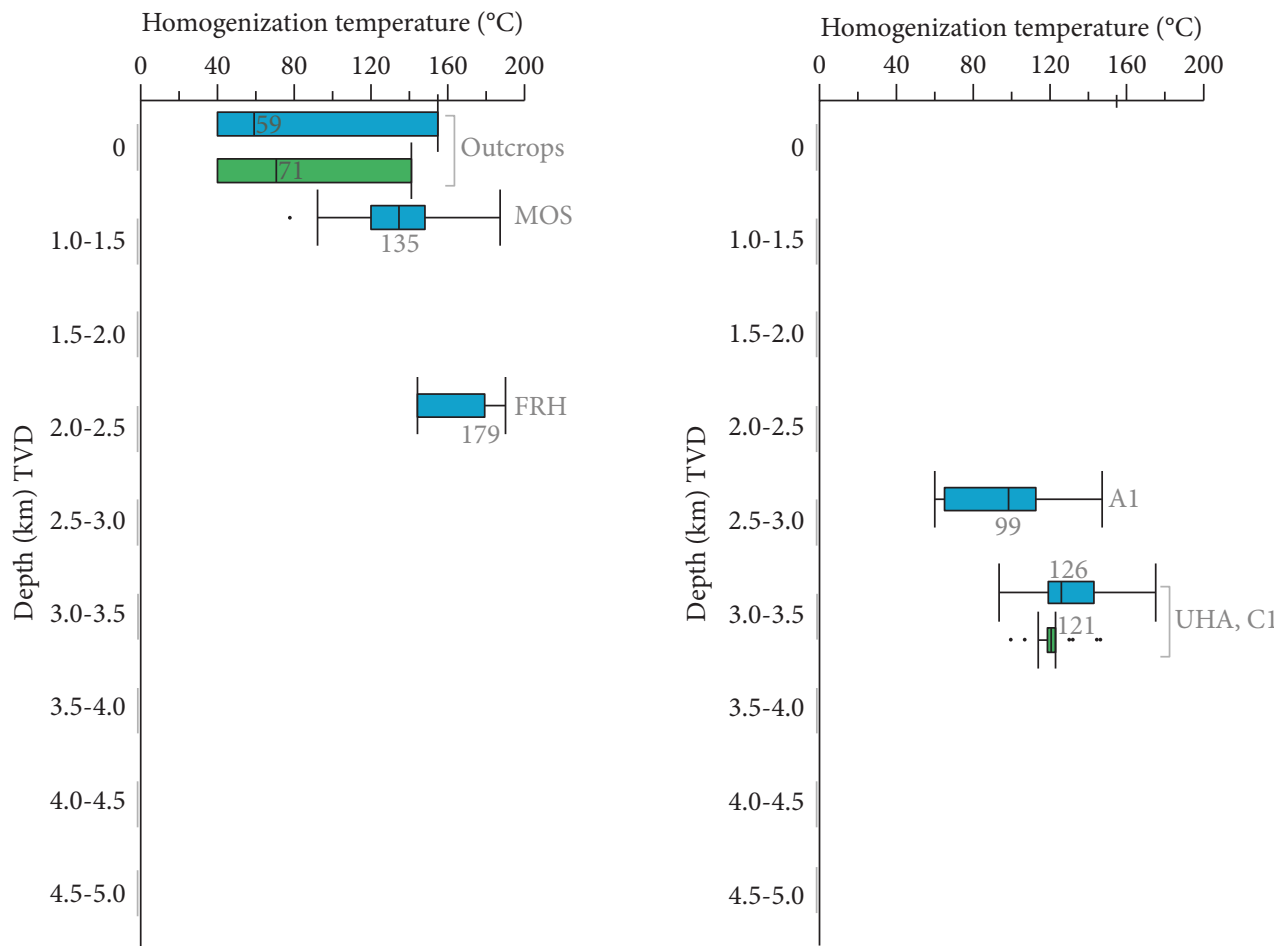

Primary

Secondary or

pseudo-secondary

Homogenization temperature $\left({ }^{\circ} \mathrm{C}\right)$
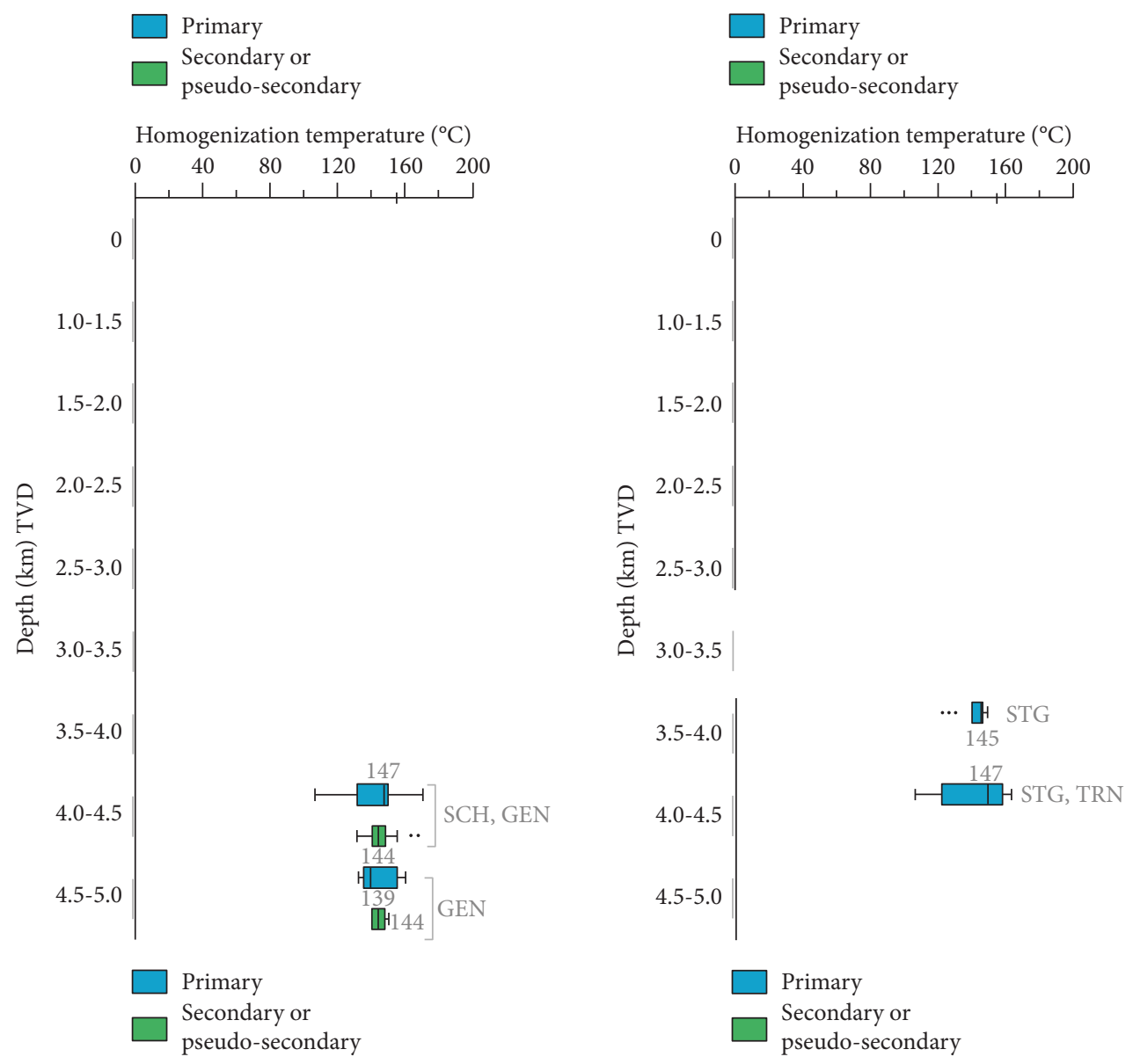

Figure 8: Boxplots of homogenization temperature versus true vertical depth of the calcite and dolomite 2-phase fluid inclusions from the wells in the Molasse Basin. In gray, the sampled wells are named using the same abbreviation as Figure 1. 


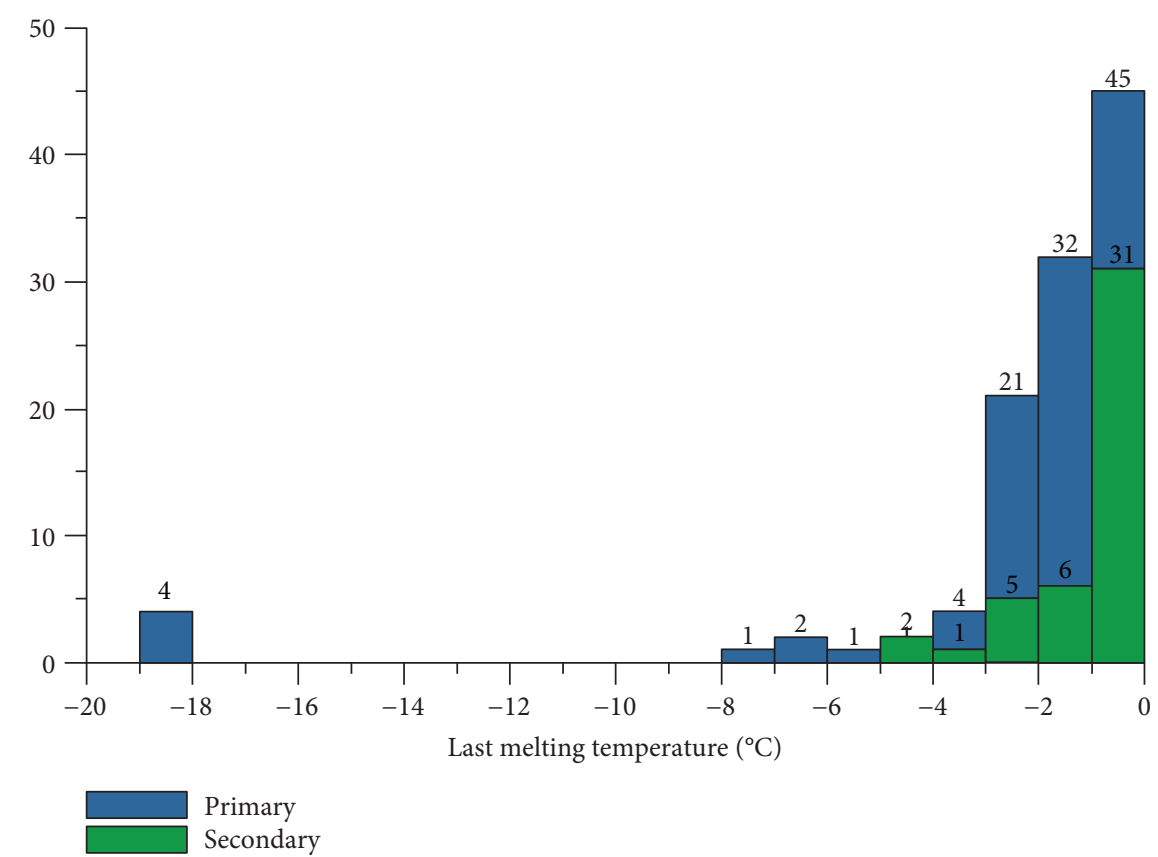

Figure 9: Histogram of the distribution of the last melting temperature $\left(T_{\mathrm{m}}\right)$ measured in primary, secondary, or pseudo-secondary fluid inclusions in calcite crystals linked to fractures and dolomite crystals.

and $\delta^{13} \mathrm{C}$ decreased from the dark (+2.5\%o PDB) to the beige dolomite crystals $(+2.2 \%$ PDB) and again to the dedolomite crystals $(-7.0 \% \mathrm{PDB})$. The isotopic signatures of the outcrop dolostones plotted in the area of low-temperature dolomite or at the transition zone to high thermal dolomite, which correspond to an early stage of dolomite formation [17]. Within the carbonate rock groups (limestone and dolostone), the trend with decreasing $\delta^{18} \mathrm{O}$ values and increasing $\delta^{13} \mathrm{C}$ values was visible during the evolution.

The vein calcite crystals of the Upper Jurassic were measured in the deep wells and were classified into the transparent calcite crystals of the upper part and the white calcite crystals of the lower part, associated with the brown and dark matrix dolomite. The white calcite crystals had very low $\delta^{13} \mathrm{C}$ values of around $-2.7 \%$ PDB and a low $\delta^{18} \mathrm{O}$ value of $-21.9 \%$ $\mathrm{PDB}$ in contrast to the $\delta^{13} \mathrm{C}$ value of $-2.2 \%$ PDB and the $\delta^{18} \mathrm{O}$ value of $-15.1 \%$ PDB of the transparent calcite crystals. The lower $\delta^{18} \mathrm{O}$ values of the transparent and white vein calcite crystals showed an influence of meteoric water. The white and transparent calcite crystal types precipitated from different fluids and at different diagenetic steps. The white calcite crystals were probably formed during an earlier stage of burial, as the $\delta^{18} \mathrm{O}$ values were only slightly higher for the limestones. In the surface outcrops and associated with karstified carbonate rocks, a third calcite crystal generation was observed, which had the lowest $\delta^{13} \mathrm{C}$ value of $-7.0 \%$ o $\mathrm{PDB}$ of all measured vein calcite crystals.

In general, the isotope values showed the following trends: the $\delta^{18} \mathrm{O}$ and $\delta^{13} \mathrm{C}$ values of the vein calcite crystals were significantly lower than the matrix calcite and dolomite crystals at comparable depths; the $\delta^{18} \mathrm{O}$ values of the vein calcite samples decreased with depth; the $\delta^{13} \mathrm{C}$ values of vein calcite crystals increased with depth (one outlier); the $\delta^{18} \mathrm{O}$ and $\delta^{13} \mathrm{C}$ values of matrix calcite and dolomite crystals decrease with depth (some outliers); a third vein calcite generation with low $\delta^{18} \mathrm{O}$ value and the lowest $\delta^{13} \mathrm{C}$ value were measured only at the outcrops (karst, dedolomite).

5.4. Fluid Salinity. Today, the Upper Jurassic reservoir fluid has a mineral concentration below $1 \mathrm{~g} / \mathrm{L}$ according to Mayrhofer et al. [55], Stober [56], Waber et al. [57], Stober et al. [58], and Birner et al. [59]. Tables 3 and 4 show the diagenetic fluid composition from the wells investigated in this study, the calculated diagenetic fluid salinity (equiv. $\mathrm{NaCl}$ ), the present reservoir data, and reservoir data according to Birner et al. [59].

5.5. Temperatures from Stable Isotopes. For the temperature evolution of the Upper Jurassic reservoir, the temperature was calculated using the isotope ratio for oxygen. In addition to the fluid inclusion and stable isotope measurements of Upper Jurassic carbonates, stable isotopes of recently formed calcite crystals, the so-called scales, as well as reservoir fluids were measured. The scale samples (scalings) were from the well head, filter, production pipe, and deep pump from two geothermal power plants (Unterhaching and Kirchstockach) south of Munich. Former researchers have described the $\delta^{18} \mathrm{O}$ values of the produced reservoir fluid in the range between -11.9 and $-10.4 \%$ VSMOW [55], -12.8 and $-10.6 \%$ SMOW [15]. Our fluid data in the investigated wells showed a median value of $-11.0 \%$ SMOW (-12.1 to $-10.6 \%$ o SMOW, $n=11)$. The $\delta^{18} \mathrm{O}$ values of the scales varied for the first Unterhaching well from -22.3 to $-26.7 \%$ PDB (median $-25.9 \%$ PDB; production temperature about $122^{\circ} \mathrm{C}$ ) and for the second Kirchstockach well from -26.2 to $-27.3 \%$ PDB (production temperature about $137^{\circ} \mathrm{C}$ ). To determine the formation temperature of the different scale samples, various geothermometers based on the fractionation factor between 


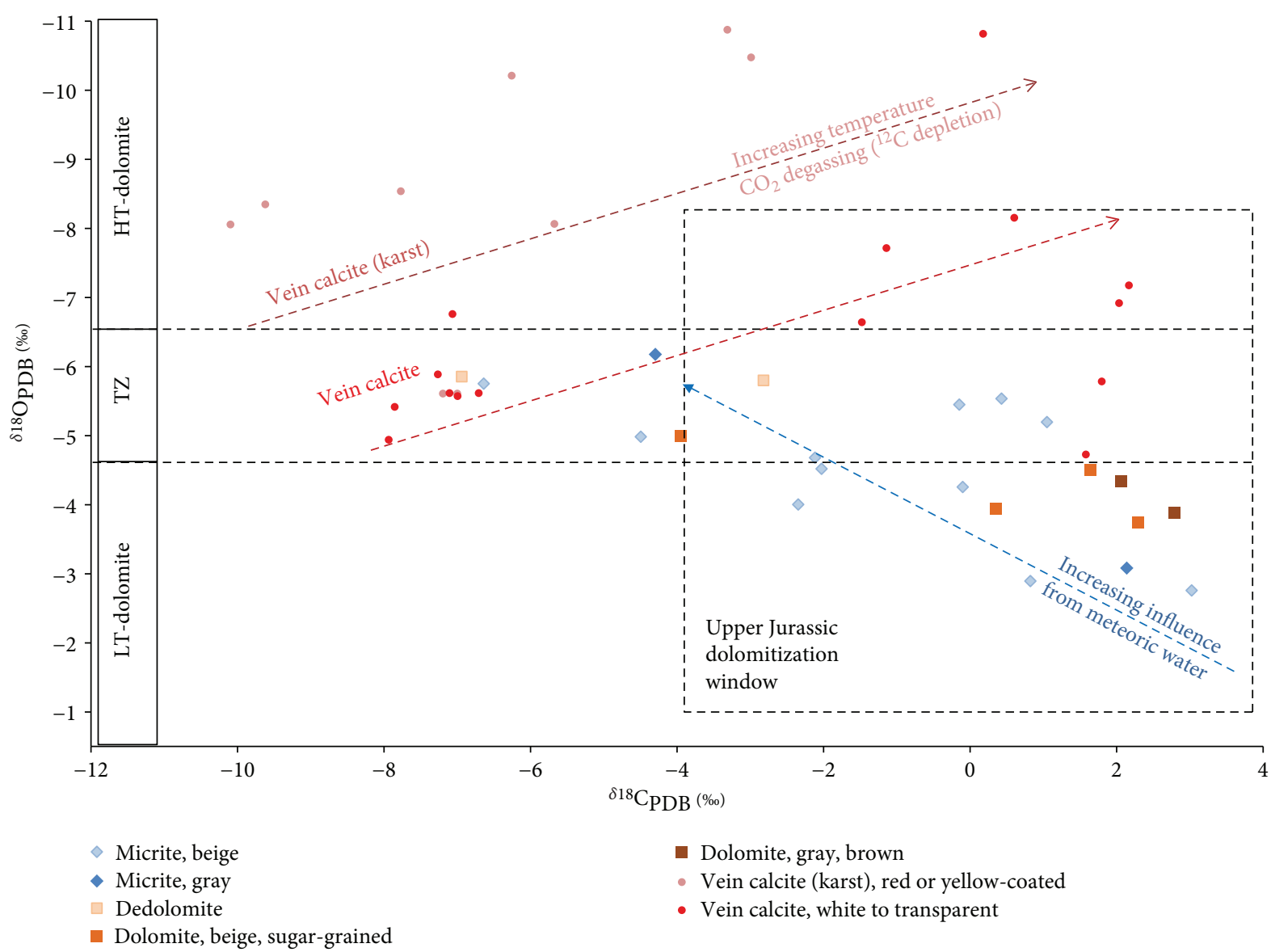

FIgURE 10: Oxygen and carbon isotopes of Upper Jurassic carbonate rocks from outcrops of the Franconian and Swabian Alb. Dashed window-Upper Jurassic dolomitization window according to Reinhold [17]. LT: low-temperature dolomites; HT: high-temperature dolomites; TZ: transition zone according to Allan and Wiggins [54]. The arrow lines with a trend of increasing meteoric influence according to Liedmann [18].

${ }^{18} \mathrm{O} /{ }^{16} \mathrm{O}$ of calcite and ${ }^{18} \mathrm{O} /{ }^{16} \mathrm{O}$ of the fluid were tested $[64$, 65]. The geothermometer values according to Friedman and O'Neil [64] showed the best match with our data (Figure 12). The formation temperature of the scales was calculated to be around $119.1^{\circ} \mathrm{C}$ for the first Unterhaching well and around $135.8^{\circ} \mathrm{C}$ for the second Kirchstockach well. Lower temperatures than the reservoir temperature represented a scale formation during downtime periods of the power plant, whereas higher temperatures represented scales in close proximity to the pump (motor temperatures up to $\left.175^{\circ} \mathrm{C}\right)$.

The paleofluid of the Upper Jurassic ocean was around $-1.0 \%$ SMOW according to Prestel [12] and Wallmann [66]. The paleotemperature of the Upper Jurassic ocean has been determined to be around 18.6 to $24.8^{\circ} \mathrm{C}[18,67]$. Saline waters with current $\delta^{18} \mathrm{O}$ values of up to $+5.5 \%$ o SMOW were observed at one Upper Jurassic well (STG) in the western part of the Molasse Basin. Liedmann [18] determined two geothermometer equations: (Geo-1) to calculate the paleotemperature supported by fluid inclusion studies with $\delta^{18} \mathrm{O}$ values of calcites and $\delta^{18} \mathrm{O}$ values of dolomite crystals of the Upper Jurassic with a maximum temperature of $110^{\circ} \mathrm{C}$. Additionally, the paleotemperatures were calculated using two equations (Geo-2) concerning the fractionation factor between ${ }^{18} \mathrm{O} /{ }^{16} \mathrm{O}$ of calcite and ${ }^{18} \mathrm{O} /{ }^{16} \mathrm{O}$ of the fluid for calcite [64] (Figure 12) and for dolomite [67], which was previously developed in this study to be the best fit with the scaling measurements. The temperature results for calcite crystals which had precipitated from Jurassic seawater with $\delta^{18} \mathrm{O}$ values of $-1 \%$ SMOW and $-11 \%$ SMOW for the recent fluids are shown in Table 6. At -11\% SMOW, the calculated temperatures using the Geo-2 equation for minerals precipitating from paleofluids were too low, as this equation could only be applied to recent nondiagenetic fluids. However, at -1\% SMOW (Jurassic seawater), all temperatures from the Geo-2 equation for precipitating minerals from paleofluids showed paleotemperatures comparable to Liedmann [18] (Geo-1).

For the other well samples, the paleotemperature was calculated using the ${ }^{18} \mathrm{O}$ geothermometer in line with Liedmann [18] with the separation at different mineral phases and depths. The micritic limestones showed (Figure 13) the lowest median at around $30-40^{\circ} \mathrm{C}$. The ${ }^{18} \mathrm{O}$ geothermometer temperature increased from the dolostones, $45^{\circ} \mathrm{C}$ to a maximum of $100^{\circ} \mathrm{C}$, to the vein calcites with a temperature range between $100^{\circ} \mathrm{C}$ and $200^{\circ} \mathrm{C}$ (Figure 13). Consequently, the temperature as well as the burial depth increased from the limestone to the dolostone and had their highest values at 


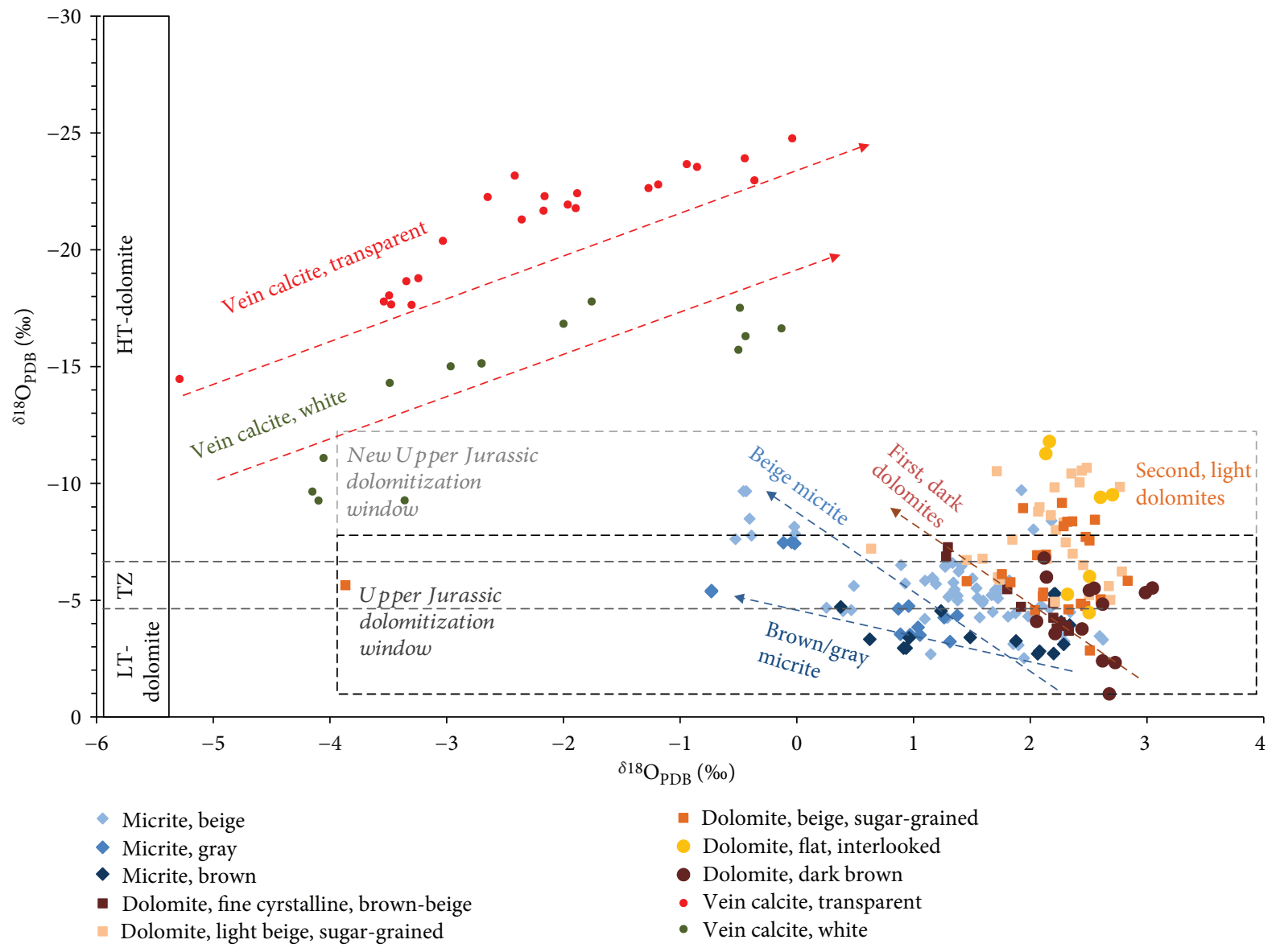

Figure 11: Oxygen and carbon isotopes of Upper Jurassic carbonates from deep wells of the southern Molasse Basin. Dashed window-Upper Jurassic dolomitization window according to Reinhold [17]; the new interpreted Upper Jurassic dolomitization window, LT: low-temperature dolomites; HT: high-temperature dolomites; TZ: transition zone according to Allan and Wiggins [54]. Arrow lines with a trend of increasing meteoric influence according to Liedmann [18].

TABLE 2: Isotope data of different rock types of the Upper Jurassic from the Molasse Basin.

\begin{tabular}{|c|c|c|c|c|c|c|}
\hline \multirow{2}{*}{ Rock type } & \multirow{2}{*}{ Stratigraphy } & \multirow{2}{*}{ Mineral } & \multirow{2}{*}{ Rock color } & \multirow{2}{*}{$n$} & \multicolumn{2}{|c|}{ Median } \\
\hline & & & & & $\delta^{18} \mathrm{O}[\% \mathrm{PDB}]$ & $\delta^{13} \mathrm{C}[\% \mathrm{PDB}]$ \\
\hline Limestone & ti-ox & $\mathrm{cc}-\mathrm{m} 3$ & Brown & 16 & -3.4 & +2.0 \\
\hline Limestone & ti-ox & $\mathrm{cc}-\mathrm{m} 2$ & Gray & 15 & -4.3 & +1.0 \\
\hline Limestone & ti-kim & $\mathrm{cc}-\mathrm{m} 1$ & Beige & 61 & -5.4 & +1.4 \\
\hline Dolostone & $\mathrm{ti}$ & dol-2 & Brown & 10 & -4.5 & +2.2 \\
\hline Dolostone & kim-ox & dol-2 & Brown & 13 & -4.8 & +2.5 \\
\hline Dolostone & ti-ox & dol-3 & Beige, massive & 30 & -6.1 & +2.3 \\
\hline Dolostone & ti-ox & dol-1 & Beige, sugar-grained & 27 & -7.5 & +2.2 \\
\hline Vein-calcite & kim-ox & cc-v1 & White & 14 & -15.1 & -2.7 \\
\hline Vein-calcite & ti-kim & cc-v2 & Transparent & 23 & -21.9 & -2.2 \\
\hline${ }^{*}$ De-dolomite & ti-kim & cc-dd & Light-beige & 2 & -5.3 & -4.9 \\
\hline${ }^{*}$ Vein-calcite & ti-kim & cc-v12 & White, transparent & 16 & -5.8 & -2.1 \\
\hline${ }^{*}$ Karst-calcite & ti-kim & cc-v3 & Yellow to red-coated crystals & 9 & -7.9 & -7.0 \\
\hline
\end{tabular}

${ }^{*}$ Data from outcrop samples. $\mathrm{n}=$ sample count. stratigraphy—origin of samples: $\mathrm{ti}=$ Tithonian; kim $=$ Kimmeridgian; ox = Oxfordian .

the vein calcites. The dolostone samples from the Geretsried well showed further an increase in temperature from the dark to the beige dolostones, as well as from the massive to the idiomorphic dolostones. By the vein calcites, a basin-wide comparison is possible, showing an increase in temperature from white vein calcites at the St. Gallen well in the 
TABLE 3: Fluid composition of the geothermal wells in the southern Molasse Basin.

\begin{tabular}{lcc}
\hline Well & Salinity from FI data $(\mathrm{g} / \mathrm{L})$ & $\begin{array}{c}\text { Salinity }(\mathrm{g} / \mathrm{L}) \\
\text { reservoir in production }\end{array}$ \\
\hline STG & 33 & ${ }^{*} 18.0$ \\
A1 & 112 & ${ }^{* *} 0.5-10.6$ \\
MOS & 12 & ${ }^{* * *} 0.2-2.0$ \\
C1 & 9 & ${ }^{* *} 5.0-10.0$ \\
SCH & 18 & $* * 5.0-10.0$ \\
FRH 1 & 19 & 4.1 \\
GEN & 27 & 1.6 \\
UHA 1 & 18 & 0.6 \\
TRN 1 & 42 & 0.5 \\
\hline
\end{tabular}

Recent well data were provided by Florian Heine, Technical University of Munich (TUM), Chair of Hydrogeology. ${ }^{*}$ Wolfgramm et al. [60], ${ }^{* *}$ Birner et al. [59], and ${ }^{* * *}$ Stober et al. [58].

west to the transparent vein calcites, like the Traunreut well in the east. However, the Traunreut well has in comparison to the other studied transparent vein calcite well samples a relative low temperature for the transparent vein calcites.

\section{Use of Cuttings for Fluid Inclusion Analyses}

In this study, we used our new approach for the fluid inclusion measurements on drill cuttings in their unprepared and unpolished form. To determine the $T_{\mathrm{h}}$ and $T_{\mathrm{m}}$ from drill cuttings, the measurements were conducted 2-3 times on cuttings with a flat and smooth surface, as well as with low heating and cooling rates. In comparison to the conventional thick sections from bore cores, the measurements of the $T_{\mathrm{h}}$ and $T_{\mathrm{m}}$ of the drill cuttings were confirmed at the Geretsried well. The mean $T_{\mathrm{h}}$ in the drill cuttings was $145^{\circ} \mathrm{C}(n=64)$ and in thick sections $143^{\circ} \mathrm{C}(n=16)$, with both samples from a similar depth. Summarizing, fluid inclusion studies of drill cutting samples expanded our study area to sites where no other rock samples were available, with the advantage of still measuring a direct sample from the diagenetic system.

\section{Paleofluid Evolution in the Upper Jurassic Reservoir in the Molasse Basin}

We analyzed the paleofluid evolution of fluids stored in the crystals of the Upper Jurassic reservoir rocks using the isotope data and fluid inclusion measurements. Isotope data (Figures 10 and 11, Table 2) were further used to extend the burial history based on sedimentological and lithological data (Figure 4). Fluids were divided into four main types based on isotope data: (1) Upper Jurassic seawater, (2) meteoric water (ground water or rainfall), and (3) basinal as well as (4) evaporated or diagenetic fluids with high salinity. The diagenetic evolution was very broadly divided into five steps (Figure 14): (I) sedimentation; (II) early diagenesis with the first dolomitization; (III) burial diagenesis with a second dolomitization; (IV) late burial diagenesis, dominant in fractures and fault systems; and (V) the present reservoir.
7.1. Phase I-Sedimentation. In the first diagenetic step (sedimentation), two primary facies types, the massive and bedded, were lithified and gave two limestone types. The light-gray limestones of the reef facies mainly consists of pure carbonate and had a high primary porosity [68] in contrast to the more impure clay-bearing limestone of the lagoon and basin facies. The fluid evolution started with the stored Jurassic seawater, which was afterward influenced by various diagenetic processes and diagenetic fluids, depending on the facies type, mineralogy during burial, and/or differences in permeability. Paleofluids during the Upper Jurassic sedimentation had $\delta^{18} \mathrm{O}$ values of approximately -1\%o SMOW for the ocean water, about $-3 \%$ SMOW at a depth of $100-$ $200 \mathrm{~m}$, and can be expected to be in the range of -4 to $-5 \%$ SMOW at a depth of 400-500 $\mathrm{m}$ [37, 69]. The one-phase fluid inclusions showed no phase changes during heating and freezing, but have probably been trapped at low temperatures with formation temperatures below $50^{\circ} \mathrm{C}$, as suggested by Goldstein [50]. The dense, brown micritic limestones showed isotopic temperatures between 30 and $40^{\circ} \mathrm{C}$, and the porous, beige micritic limestones were between 30 and $50^{\circ} \mathrm{C}$. The bulk measurements of the beige micritic limestone, which contains matrix dolomite, indicated an increased temperature due to the lower $\delta^{18} \mathrm{O}$ values of the dolomite crystals (-5.4\% PDB instead of the $-3.4 \%$ PDB for the limestone). The temperatures at the top of the sediment during deposition were approx. at $25^{\circ} \mathrm{C}$ [18]. Consequently, the limestone cements and matrix dolomite crystals were formed at a depth of 300 to $650 \mathrm{~m}$.

7.2. Phase II-Early Diagenesis with First Dolomitization. Afterward, the early diagenesis with the first dolomitization period occurred in a gradual transition from the sedimentation phase. The early diagenetic stage was characterized by an intense dolomitization of carbonate rocks in contact with meteoric and basinal fluids [17, 18, 30, 70]. The dark dolostone was possibly formed from dark micritic limestone in lagoons and basins with a potentially high organic matter. The formation temperature of the dolomite crystals was between $50^{\circ} \mathrm{C}$ and $70^{\circ} \mathrm{C}$, with lower values for the brown and dark dolostones compared to the beige dolostones. The temperature increased from the limestones to the dolostones, suggesting dolomite formation at greater depths. Due to the higher formation temperatures, the dolostones $(-4.5 \%$ o to $-7.5 \%$ PDB) generally showed lower $\delta^{18} \mathrm{O}$ values of around $-1.5 \%$ o PDB in contrast to the limestones $(-3.4 \%$ o to $-5.4 \%$ o $\mathrm{PDB})$. The three parameters increasing influence of meteoric fluids, increasing temperature, and/or fluid-rock interactions in an open system seem to be responsible for the decrease in $\delta^{18} \mathrm{O}(-3.4 \%$ PDB to $-5.4 \%$ PDB limestones; $-4.5 \%$ PDB to $-7.5 \%$ PDB dolostones) with increasing depth and temperature (Figure 10) $[69,71]$. Due to the higher reservoir temperature in the southern deeper reservoir part, some of the carbonate values from the deep wells did not plot in the "Upper Jurassic dolomitization window" (Figure 11) according to Liedmann [18] and Reinhold [17], which we used in this study. The carbonate rocks analyzed by Liedmann [18] and Reinhold [17] were sampled from around 50 outcrops of the Oxfordian and Kimmeridgian from the Swabian and 
TABle 4: Hydrochemical data from the deep wells showing a dilution of the Jurassic seawater from the St. Gallen well [61], Geretsried, Unterhaching, and the most diluted formation water at the Traunreut well.

\begin{tabular}{lcccccccccc}
\hline Parameter & \multicolumn{2}{c}{ Jurassic seawater } & \multicolumn{2}{c}{ St. Gallen } & \multicolumn{2}{c}{ Geretsried } & \multicolumn{2}{c}{ Unterhaching } & \multicolumn{2}{c}{ Traunreut } \\
& $(\mathrm{g} / \mathrm{L})$ & $(\%)$ & $(\mathrm{g} / \mathrm{L})$ & $(\%)$ & $(\mathrm{g} / \mathrm{L})$ & $(\%)$ & $(\mathrm{g} / \mathrm{L})$ & $(\%)$ & $(\mathrm{g} / \mathrm{L})$ & $(\%)$ \\
\hline Sodium & 10.7 & 30.5 & 6 & 30.9 & 0.8 & 26.5 & 0.12 & 17.5 & 0.13 \\
Potassium & 0.4 & 1.1 & 2.2 & 11.3 & 0.08 & 2.6 & 0.02 & 2.9 & 0.02 & 3.6 \\
Magnesium & 1.3 & 3.7 & 0.03 & 0.2 & 0.02 & 0.7 & 0.005 & 0.7 & 0.004 & 0.7 \\
Calcium & 0.4 & 1.1 & 0.12 & 0.6 & 0.1 & 3.3 & 0.03 & 4.4 & 0.03 & 5.4 \\
Chloride & 19.3 & 55.0 & 9.6 & 49.5 & 1.4 & 46.4 & 0.11 & 16.1 & 0.08 & 14.4 \\
Sulphate & 2.7 & 7.7 & 0.15 & 0.8 & 0.08 & 2.6 & 0.02 & 2.9 & 0.01 & 1.8 \\
HCO $_{3}{ }^{-}$ & 0.2 & 0.6 & 1.2 & 6.2 & 0.44 & 14.6 & 0.28 & 40.9 & 0.28 & 50.5 \\
Residual & 0.1 & 0.3 & 0.1 & 0.5 & 0.1 & 3.3 & 0.1 & 14.6 & $<0.1$ & $<18.1$ \\
Sum & 35.1 & 100 & 19.4 & 100 & 3.02 & 100 & 0.685 & 100 & 0.554 \\
\hline
\end{tabular}

The determined, calculated, and measured temperatures of the Upper Jurassic aquifer are shown in Table 5 . The $T_{\mathrm{h}}$, trapping, and maximum trapping temperatures measured in the vein calcites using microthermometry were higher than the recent reservoir temperature in nearly every measured well. However, the reservoir temperature was not corrected for the borehole temperature BHT and could have an error of around $20 \mathrm{~K}$.

TABlE 5: Temperature measurements of the recent reservoir temperatures from unpublished borehole reports.

\begin{tabular}{|c|c|c|c|c|}
\hline Well & $\begin{array}{l}\text { Top T UJR } \\
\left({ }^{\circ} \mathrm{C}\right)\end{array}$ & $\begin{array}{l}\text { Max. T UJR } \\
\quad\left({ }^{\circ} \mathrm{C}\right)\end{array}$ & $\begin{array}{l}T_{\mathrm{h}} \\
\left({ }^{\circ} \mathrm{C}\right)\end{array}$ & $\begin{array}{l}\text { Top T UJR GeotIS } \\
\left({ }^{\circ} \mathrm{C}\right)[62]\end{array}$ \\
\hline STG & 144 & 150 & $\begin{array}{l}140- \\
156\end{array}$ & - \\
\hline A1 & 104 & 104 & $\begin{array}{l}70- \\
130\end{array}$ & $100 \pm 11$ \\
\hline MOS & $79^{*}$ & $87^{*}$ & 130 & $70 \pm 7$ \\
\hline $\mathrm{C} 1$ & - & - & 123 & $108 \pm 11$ \\
\hline $\mathrm{SCH}$ & 128 & 131 & $\begin{array}{c}122- \\
158\end{array}$ & $133 \pm 12$ \\
\hline FRH & & 105 & $\begin{array}{c}144- \\
190\end{array}$ & $80 \pm 11$ \\
\hline GEN & 125 & 150 & $\begin{array}{c}141- \\
148\end{array}$ & $147 \pm 14$ \\
\hline UHA & 91 & 124 & $\begin{array}{l}123- \\
135\end{array}$ & $118 \pm 11$ \\
\hline TRN & 106 & 115 & $\begin{array}{l}106- \\
115\end{array}$ & $108 \pm 11$ \\
\hline
\end{tabular}

UJR: Upper Jurassic reservoir; Top T: temperature at top of UJR; Max. T UJR: maximum temperature of the UJR; $T_{\mathrm{h}}$ : homogenization temperature from fluid inclusions; Top T UJR GeotIS: temperature data according to Agemar et al. [62]. —no data available; *Schneider et al. [63].

Franconian Alb and sampled at eight shallow wells with a maximum depth of $930 \mathrm{~m}$ in the western Molasse Basin. Therefore, we had to include higher temperatures and lower $\delta^{18} \mathrm{O}$ values of the Upper Jurassic dolomitization window (Figure 11) in the present study.

7.3. Phase III-Burial Diagenesis with Second Dolomitization. The formation temperature of idiomorph dolomite crystals was around $120-136^{\circ} \mathrm{C}$ at depths of $3050-3100 \mathrm{~m}$ TVD at Traunreut, colder than the later vein calcite crystals at the same depths, but hotter than the first phase dolomites. With the recent geothermal gradient of $25 \mathrm{~K} / \mathrm{km}$ at the Traunreut well, the formation temperature of the dolomite crystals should only be around $75-80^{\circ} \mathrm{C}$. In addition, the dolomite crystals showed a high salinity with $40 \mathrm{~g} / \mathrm{L} \mathrm{NaCl}$ equiv. compared to the later formed blocky, vein calcite crystals, with a salinity of $10 \mathrm{~g} / \mathrm{L}$ to $20 \mathrm{~g} / \mathrm{L} \mathrm{NaCl}$ equiv. The decrease in $\delta^{13} \mathrm{C}$ or lower $\delta^{13} \mathrm{C}$ in the limestones $(+1.4$ to $+2.0 \%$ PDB) to the vein calcites ( -2.2 to $-2.7 \%$ PDB) may result from an increasing influence of meteoric fluids or a higher content of organic carbon [69]. In contrast, the increase in $\delta^{13} \mathrm{C}$ from the limestones $(+1.4$ to $+2.0 \%$ o $\mathrm{PDB})$ to the dolostones $(+2.2$ to $+2.5 \%$ PDB) may result from $\mathrm{CO}_{2}$-degassing, due to the hydrocarbon emplacement, or an inflow of marine waters (Figure 10) of the bedded facies [69]. The main dolomitization occurred during the burial phase and is in line with previous studies $[17,18]$. This second phase of dolomitization in combination with bitumen or hydrocarbons and a higher formation temperature has not been described for the Upper Jurassic reservoir before.

7.4. Phase IV-Late Burial Diagenesis. During the Paleogene and foreland basin development, the late burial diagenesis in the Upper Jurassic carbonate rocks happened, which was characterized by faulting, high subsidence rates, and higher temperatures due to increased burial depths. The white vein calcite crystals showed a strong fingerprint of basinal water with $\delta^{13} \mathrm{C}$ values of $-2.1 \%$ PDB and $\delta^{18} \mathrm{O}$ values of $-5.8 \%$ $\mathrm{PDB}$. In contrast, the transparent calcite crystals of the upper part of the Upper Jurassic were formed from meteoric fluids during late diagenesis with $\delta^{13} \mathrm{C}$ values of $-2.2 \%$ PDB and $\delta^{18} \mathrm{O}$ values of $-21.9 \%$ PDB. The isotope temperature values for the limestones and dolostones seemed reliable, whereas the isotope temperature results of the vein calcite crystals from the deep wells were up to $216^{\circ} \mathrm{C}$ higher than the recent reservoir temperature. However, the geothermometer equation (Geo-1) [18] was extended in this study to temperatures above $110^{\circ} \mathrm{C}$, due to the application and validation of the equation by Liedmann at higher temperatures (max. $200^{\circ} \mathrm{C}$ ). The fluid salinity of the blocky calcite was below seawater $\left(35 \mathrm{~g} / \mathrm{L} \mathrm{NaCl}\right.$ equiv.) with a $T_{\mathrm{m}}$ of $-1.0^{\circ} \mathrm{C}(17 \mathrm{~g} / \mathrm{L} \mathrm{NaCl}$ equiv.) for primary inclusions and $-0.7^{\circ} \mathrm{C}(12 \mathrm{~g} / \mathrm{L} \mathrm{NaCl}$ equiv.) for secondary or pseudo-secondary inclusions. 


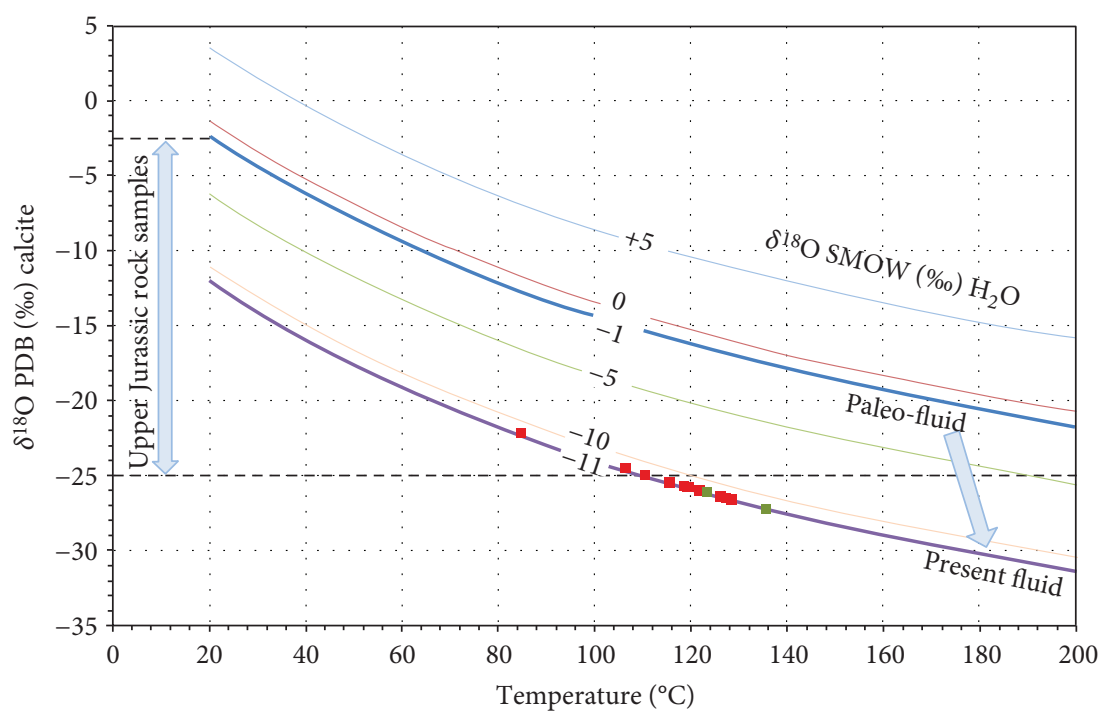

FIGURE 12: Isotope composition of water versus calcite crystals according to Friedman and O'Neil [64]; red squares-scaling from the Unterhaching geothermal plant, green squares_-scaling from the Kirchstockach geothermal plant.

Furthermore, there were fluids with a higher salinity with $T_{\mathrm{m}}$ between $-2.0^{\circ} \mathrm{C}$ and $-18.0^{\circ} \mathrm{C}$ and salinity between 33 and $112 \mathrm{~g} / \mathrm{L} \mathrm{NaCl}$ equiv. in the southernmost and westernmost wells such as St. Gallen and A1. At the St. Gallen well, an increase in salinity with increasing depth was measured from $28 \mathrm{~g} / \mathrm{L}$ to $34 \mathrm{~g} / \mathrm{L} \mathrm{NaCl}$ equiv. This increase in salinity with depth was also described by Liedmann [18] with $T_{\mathrm{m}}$ between -2.0 and $-5.0^{\circ} \mathrm{C}$. At the Geretsried well, a variable fluid salinity was measured starting with $34 \mathrm{~g} / \mathrm{L} \mathrm{NaCl}$ equiv. (primary) to $64 \mathrm{~g} / \mathrm{L} \mathrm{NaCl}$ equiv. (secondary 1) and $12 \mathrm{~g} / \mathrm{L} \mathrm{NaCl}$ equiv. (secondary 2), respectively. Those different secondary or pseudo-secondary salinities may have been caused by the influence of two different saline fluids. This fluid salinity of the late calcite cements was consistent to the data by Liedmann [18] for the outcrops and shallow boreholes. The higher saline fluids might have their source in the Upper or Middle Triassic [17], the Purbeck (latest Tithonian to earliest Berriasian) or the lower Oligocene sediments ([23]; 1976). The Triassic and the Oligocene salt waters are unlikely sources for the following reasons: a Triassic fluid would have had to migrate against the hydraulic pressure, because the Triassic aquifer is underpressured; the Oligocene aquifer is underpressured as well and would need to flow against the higher pressure of the Upper Jurassic aquifer [72]. Therefore, neither ascending nor descending saline fluids were assumed. The Purbeck sediments are brecciated and micritic limestones, which were deposited under brackish to evaporitic conditions during the late Upper Jurassic and early Lower Cretaceous [73]. Therefore, a potential source area of the salts in the Upper Jurassic reservoir could be the Purbeck rocks (latest Upper Jurassic to earliest Lower Cretaceous). Beside clathrates, another cause of the positive $T_{\mathrm{m}}$ in small fluid inclusions is metastability, which may have caused the changing, but persistently positive $T_{\mathrm{m}}$ with a fast gas bubble formation. Therefore, no $\mathrm{CO}_{2}$ or $\mathrm{CH}_{4}$ gases were assumed to be contained in the fluid inclusions [74]. This was unexpected, as hydrocarbons are stored in the Upper Jurassic rocks and should be present in the fluid inclusions.

7.5. Phase V-The Present Stage. The present reservoir has been explored by hydrocarbon and geothermal wells and records the last diagenetic phase of our study. Downwardmigrating fluids, probably from rainfall, moving along faults and karst phenomena may have lowered the $\delta^{18} \mathrm{O}$ reservoir values to the recently measured $-11 \%$ SMOW $(-12.1$ to $-10.6 \%$ SMOW, $n=11$ ). The diagenetic fluid salinity (equiv. $\mathrm{NaCl}$ ) in late calcite crystals in veins has a mean value of $32.0 \mathrm{~g} / \mathrm{L} \mathrm{NaCl}$ equiv., which is higher than the present reservoir salinity (mean value: $4.8 \mathrm{~g} / \mathrm{L}$ ). In addition, the salinity of the reservoir fluid varies depending on the location of the well (Figure 15) [59]. Prestel [12] reported an increase in the salinity of the fluid reservoir to the south with a salinity of up to $37 \mathrm{~g} / \mathrm{L}$ at the Opfenbach hydrocarbon well. Today, the reservoir water signature should be characterized by the diluted Upper Jurassic seawater with meteoric water and by dissolved salts in the western area [75]. In the southwest, the increase in salinity might be caused by a reduced exchange of fluids due to the lower permeability. The relative high $\delta^{18} \mathrm{O}$ values of up to $+5.5 \%$ SMOW of the present reservoir water in this area probably results from evaporitic or diagenetic processes. The only possible pathways for fluid flow must then be along fault systems. The hydrochemical data support the theory that the Jurassic seawater was diluted by a meteoric water, as determined by stable isotopes and fluid inclusions (Table 4). In this study, the source area of the meteoric fluids was not determined, but previous researchers described the origin in the Swabian and Franconian Alb [12]. Because the ancient Jurassic seawater had a salinity of around $35 \mathrm{~g} / \mathrm{L} \mathrm{[18]}$, the reservoir fluid became less saline during the evolution of the foreland basin with a fluid salinity in late vein cements of around $10-20 \mathrm{~g} / \mathrm{L}$ $\mathrm{NaCl}$ equiv., and the present salinity with the lowest salinity 
TABLE 6: Paleotemperature from isotopic geothermometers ( $\delta^{18} \mathrm{O}$ values Table 2$)$; Geo-1: ${ }^{18}$ O geothermometers according to Liedmann [18]; Geo-2: ${ }^{18} \mathrm{O}$ geothermometer after Friedman and O'Neil [64] for calcite and Fritz and Smith [67] for dolomite and for paleofluids with an ${ }^{18} \mathrm{O}$ value of $-1 \%$ SMOW and $-11 \%$ SMOW; bold-reliable data.

\begin{tabular}{|c|c|c|c|c|c|c|c|c|}
\hline \multirow[t]{2}{*}{ Mineral } & \multirow[t]{2}{*}{ Properties } & \multirow{2}{*}{$\begin{array}{c}\mathrm{T}\left({ }^{\circ} \mathrm{C}\right) \text { Geo-1 } \\
\text { Median }\end{array}$} & \multicolumn{3}{|c|}{$\mathrm{T}\left({ }^{\circ} \mathrm{C}\right) \mathrm{Geo} 2(-1 \%)$} & \multicolumn{3}{|c|}{$\mathrm{T}\left({ }^{\circ} \mathrm{C}\right) \mathrm{Geo} 2(-11 \% \mathrm{o})$} \\
\hline & & & Min & Median & $\operatorname{Max}$ & Min & Median & $\operatorname{Max}$ \\
\hline $\mathrm{cc}-\mathrm{m} 1$ & Brown & 30.2 & 21.7 & 25.0 & 43.3 & 10.7 & 11.5 & 12.3 \\
\hline $\mathrm{cc}-\mathrm{m} 2$ & Gray & 35.5 & 22.9 & 30.1 & 31.6 & & 10.6 & 12.0 \\
\hline cc-m3 & Beige & 41.7 & 20.7 & 35.8 & 40.1 & & 10.2 & 12.6 \\
\hline dol-2 & Brown, fine crystalline & 54.9 & 53.1 & 57.5 & 247.9 & 7.8 & 11.3 & 117.9 \\
\hline dol-2 & Dark-brown, interlocked & 57.3 & 39.2 & 59.5 & 71.9 & -4.5 & 12.8 & 21.5 \\
\hline dol-3 & Beige, massive & 66.0 & 48.5 & 67.1 & 111.0 & 4.0 & 18.2 & 44.7 \\
\hline dol-1 & Beige, sucrosic & 76.8 & 60.2 & 76.4 & 101.0 & 13.3 & 24.4 & 39.1 \\
\hline cc-v1 & White & 114.4 & 58.9 & 108.0 & 125.1 & 14.0 & 34.8 & 50.3 \\
\hline$c c-v 2$ & Transparent & 183.2 & 99.6 & 199.9 & 238.9 & 30.7 & 81.6 & 108.3 \\
\hline cc-dd & Light-beige & 41.0 & 35.2 & 35.2 & 35.3 & 10.2 & 10.2 & 10.2 \\
\hline cc-v12 & White-transparent & 43.8 & 29.5 & 37.7 & 43.8 & & 10.2 & 17.3 \\
\hline cc-v3 & Yellow to red coated crystals & 57.4 & 34.2 & 50.1 & 54.0 & 10.3 & 11.7 & 16.5 \\
\hline
\end{tabular}

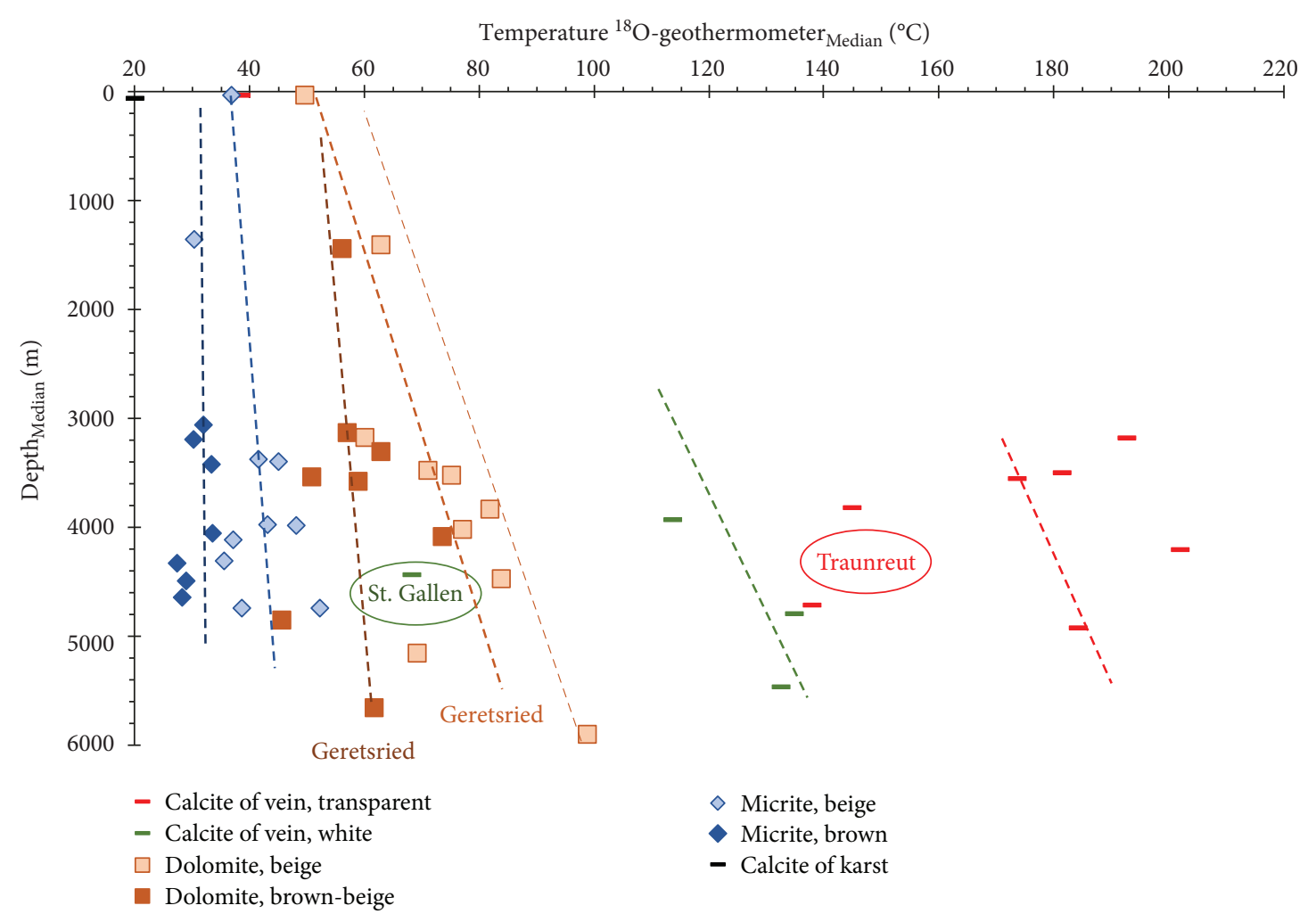

Figure 13: Temperatures calculated using the ${ }^{18} \mathrm{O}$ geothermometer versus the median of depth [18].

of $0.5 \mathrm{~g} / \mathrm{L}$. Thereby, the fluid salinity of late vein cements represents an intermediate point in the evolution of the Upper Jurassic reservoir. In addition, the concentration of dissolved ions in the reservoir fluid has decreased with time and location, from east to west. Examples are the westernmost St. Gallen well with the highest salinity and the easternmost Traunreut well with the lowest salinity of the present reservoir fluid. The greater dilution of the former Jurassic seawater in the eastern section of the reservoir could be caused by the high permeability of the carbonate rocks.

The four following reasons could explain the higher formation temperatures of around $25^{\circ} \mathrm{K}$ compared to the recent reservoir temperature: (1) ascending hotter basement fluids along fractures and fault zones, (2) necking or stretching of the fluid inclusions while heating (reequilibrium), (3) hightemperature Upper Jurassic formation fluids, and/or (4) a 


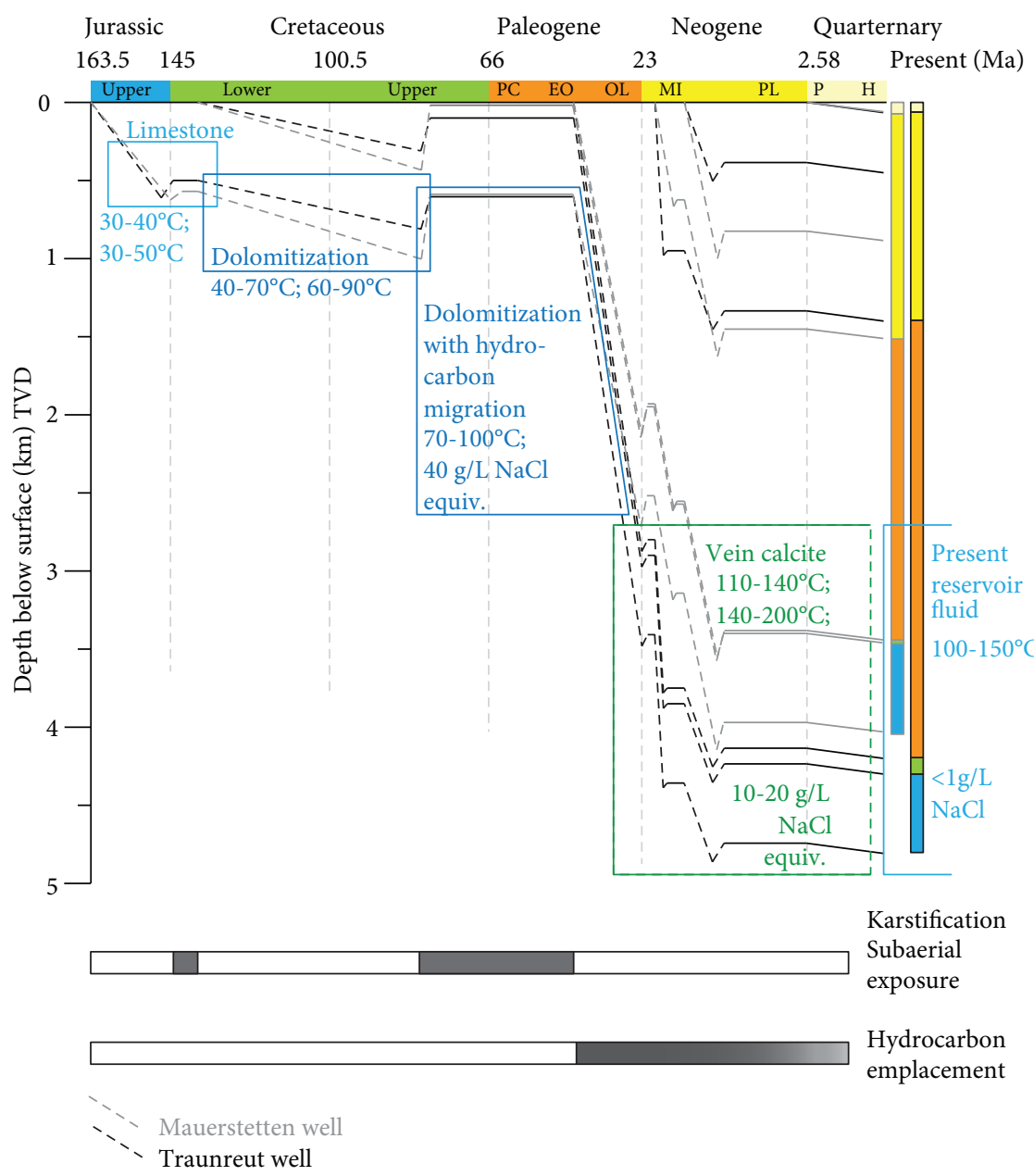

FIgURE 14: Subsidence plot for the Upper Jurassic carbonate rocks, divided into the western (gray) and eastern (black) Molasse Basin. The eastern Molasse Basin was down-lifted further than the western Molasse Basin, and both parts have reached the maximum depth today. The sediment thickness was used from the borehole data at Traunreut (eastern Molasse Basin) and Mauerstetten (western Molasse Basin) and was not corrected for compaction. Due to varying geothermal gradients, the relative depths were assumed.

higher or different geothermal gradient. As no cement phase possessed a different chemistry or isotope signature, ascending basement fluids are unlikely. The reequilibrium of the fluid inclusions means that the maximum temperature stored from reequilibrium was measured in this study [76, 77]. As large fluid inclusions are more likely to reequilibrate than small ones [51], the possibility of the small 2-phase fluid inclusions in the present study was low. Because of the similar $T_{\mathrm{h}}$ and $T_{\mathrm{m}}$ and consistent liquid-vapor ratios in the measured FIA in the vein calcites, we assumed that no reequilibrium occurred. High-temperature formation waters of the Upper Jurassic in deeper zones of the foreland basin (Figure 2) are unlikely, as the Upper Jurassic carbonate rocks in the deeper zone are low to no permeable and thus formation fluids could only migrate parallel to stylolites. However, there is still the problem of the nearly east-west-striking fault structures [78] which the migrating fluids had to overcome to migrate from the deeper zone to the sampled area in the North Alpine Foreland Basin. The higher geothermal gradient seemed to be the most relevant cause of the temperature increase, as a varying geothermal gradient would explain the high temperatures and might not cause a change in fluid chemistry. Moreover, a varying geothermal gradient would be in line with previous studies by the hydrocarbon industry for the Cenozoic sediments in the Molasse Basin [9, 44]. Liedmann [18] discussed possible paleotemperature gradients of up to $60 \mathrm{~K} / \mathrm{km}$, but this study did not confirm that. In contrast to the average geothermal gradient of the Upper Jurassic reservoir, the Traunreut well has an anomaly with a lower temperature and geothermal gradient today $[53,79]$.

7.6. Phase VI-Outcrops of the Upper Jurassic in the Molasse Basin. At the surface outcrops, the temperature from fluid inclusions $\left(50-80^{\circ} \mathrm{C}\right)$ and determined by stable isotopes (41$57^{\circ} \mathrm{C}$ ) at dedolomite cements, as well as at calcite cements showed low cement formation temperatures, due to the lower subsidence at the Franconian and Swabian Alb. Thereby, the salinity of the outcrop fluid inclusions is with $10-20 \mathrm{~g} / \mathrm{L}$ in a similar range to the values of the deep wells. Consequently, the cements at the outcrops precipitated from a similar fluid and events than the deeper reservoir section of the Molasse Basin, which is in line with previous studies $[17,18]$. 


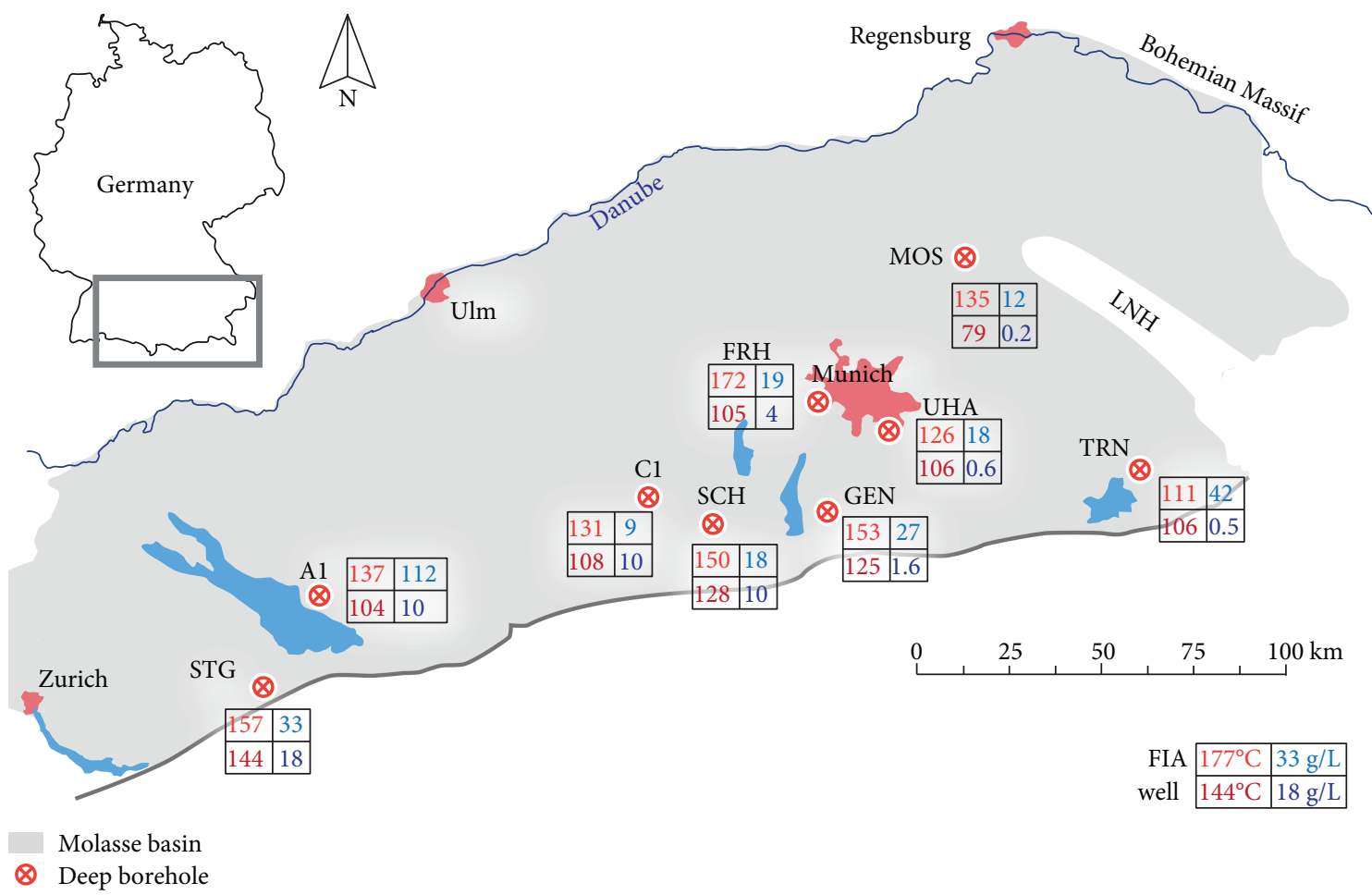

Figure 15: Overview of the study area in the Molasse Basin, southern Germany and eastern Switzerland. In addition, the measured temperature and salinity values measured in the fluid inclusion assemblage (FIA) of the cement phase of the late vein calcites and in the present reservoir fluid are given.

\section{Subsidence History from Well Data of the Molasse Basin}

The measured formation temperature in the vein calcites and dolomite crystals in combination with the reconstruction of the subsidence history, paleofluids, and paleotemperature using stable isotopes provided evidence of the foreland basin evolution (Figures 14 and 15). The evolution started with the Jurassic seawater, which had a temperature of around $25^{\circ} \mathrm{C}$ during deposition [18] at an assumed water depth of 150$200 \mathrm{~m}$ [80]. During early diagenesis, the limestone reached the burial of $200-400 \mathrm{~m}$, and the temperatures were around $30-40^{\circ} \mathrm{C}$. After the limestone cementation, the dolostones were formed at around $40-70^{\circ} \mathrm{C}$ for the brown dolostones and $60-90^{\circ} \mathrm{C}$ for the beige dolostones. The dolostones showed an increase in temperature compared to the light beige, subhedral-euhedral, pure dolostone. Due to the temperature and isotope data, the assumed depth of dolomitization is around $1-2 \mathrm{~km}$ with a possible inflow from meteoric fluids. In the further subsidence of the rocks to a depth of 1.0$2.5 \mathrm{~km}$, the dolostones with a bitumen coating were formed at temperatures between 70 and $100^{\circ} \mathrm{C}$. This probably happened during a further or second dolomitization phase, which has not been described before, and while a high migration of hydrocarbons was present. In addition, a $T_{\mathrm{h}}$ of around $110^{\circ} \mathrm{C}$ and a salinity of $40 \mathrm{~g} / \mathrm{L} \mathrm{NaCl}$ equiv. for these idiomorphic dolomite crystals (planar-e dolostones) were measured, but with no indication of hydrocarbons. The sampled dolomite crystals were either vein or fractured dolomite crystals from the Traunreut well at depths of $3086 \mathrm{~m}$ TVD. Our study confirmed the data by Liedmann [18], who assumed a deep burial hydrothermal dolomitization during the Alpine orogeny, and first dolomitization with temperatures of around $40-90^{\circ} \mathrm{C}$. Consequently, dolomitization occurred during the burial diagenesis, first at lower $\left(40-90^{\circ} \mathrm{C}\right)$ and later at higher $\left(70-100^{\circ} \mathrm{C}\right)$ temperatures. In addition, a meteoric influence was present during the diagenesis, as the former Jurassic seawater was diluted in the southern Upper Jurassic rocks during the Cretaceous and Paleogene (Figure 15), from a yet unknown source.

The highest $T_{\mathrm{h}}$ in the transparent vein calcites (Figure 15) was close to the maximum value, and it confirmed the growth of the calcite crystals at a late diagenetic stage with maximum temperatures of up to $190^{\circ} \mathrm{C}$, which was also described by Liedmann [18]. As the calcite crystals precipitated in fractures and veins, the formation must have happened during the tectonic phase of the Alpine orogeny in the Molasse Basin. However, unclear remains the age and cause of the high temperatures stored in the vein calcites. A possible future option, if new fluid inclusion data of gas concentrations are available, could lie in specifying the reconstruction of the subsidence history by $1 \mathrm{D}$ basin modelling. By this 1D basin modelling, the thermal disequilibrium of the late vein calcites could be confirmed and linked to the timing of fluid migration and regional geodynamics. The isotope temperature for the white vein calcite crystals was between $110^{\circ} \mathrm{C}$ and $140^{\circ} \mathrm{C}$, excluding St. Gallen with temperatures of $70^{\circ} \mathrm{C}$. These temperatures could be higher due to a measuring error, as the salinity of the ascending fluids might be increased from highly saline lagoon and basin fluids, and 
therefore the geothermometer from Liedmann [18] (Geo-1) could have calculated lower values. The transparent vein calcite crystals were probably formed in a second tectonically active phase because the isotope temperatures were between 140 and $200^{\circ} \mathrm{C}$, higher than the white vein calcites. Consequently, the white vein calcites were formed at depths of $1-3 \mathrm{~km}$, and the transparent vein calcites precipitated from low saline fluids (10-20 g/L NaCl equiv.) at depths between $1.0 \mathrm{~km}$ and $3.5 \mathrm{~km}$. The transparent vein calcites at the Traunreut well showed the lowest isotope temperatures, which confirmed the present low-temperature anomaly (Figure 15). Furthermore, the Traunreut well has the most diluted reservoir fluid today (Figure 15), indicating a meteoric influence with decreasing grade to the southwest. Hence, the late meteoric water was present during the growth of the transparent vein calcite, as the fluid inclusions showed the dilution of the former Jurassic seawater as well. In summary, our study showed that the early diagenetic fluids and cements might be overprinted by a hotter hydrothermal fluid migration or a higher geothermal gradient, evidenced by the vein calcites in the Upper Jurassic reservoir (Figure 15). This hot fluid migration, stored in the late vein cements, was along fault and fracture systems.

Temperatures above $50^{\circ} \mathrm{C}$ have been possible since the Eocene, which is characterized by the Paleogene sedimentation (Figure 14). Surface outcrops might have reached depths of around $600 \mathrm{~m}$ as testified by the low cement formation temperatures, and of up to $4,000 \mathrm{~m}$ in the deeper downlifted Upper Jurassic reservoir in the southern Molasse Basin (Figure 14). Using the subsidence plots (Figure 14), higher temperatures were assumed in the eastern part of the basin, as the sedimentary rocks are at greater depths. However, the Traunreut well in the eastern part of the basin showed relatively low temperatures for the vein calcites compared to the dolomitization temperatures, possibly due to an already existing temperature anomaly $[53,62]$.

\section{Conclusion}

In our study, the fluid and temperature evolution of the Upper Jurassic reservoir in the North Alpine Foreland Basin was analyzed using fluid inclusion measurements and stable isotopes of different cement phases in the carbonate rocks. In a new approach to measure fluid inclusions in drill cuttings, the study area was extended to boreholes drilled for a geothermal purpose, where drill cuttings were the only available samples. Thereby, old and newly drilled wells could be measured, and a wide area was investigated from the surface to depths of $4500 \mathrm{~m}$. The burial development of the Upper Jurassic rocks was reconstructed from temperature and fluid composition data. Our results show an early diagenesis of the limestones, followed by two burial dolomitization phases and a late, tectonically active burial phase, which developed fractures and fault zones (Figure 14). The main dolomitization phase could have occurred during the Alpine orogeny in the Cretaceous and early Paleogene. This early dolomitization might have developed at a depth of around $1-2 \mathrm{~km}$. A later, second dolomitization is characterized by idiomorphic dolomite crystals coated with bitumen and temperatures of around $80-100^{\circ} \mathrm{C}$. This second and newly described dolomitization was measured in fluid inclusions hosted in dolomite crystals with formation temperatures of around $110^{\circ} \mathrm{C}$ and a salinity of $40 \mathrm{~g} / \mathrm{L} \mathrm{NaCl}$ equiv., which is below the values of the Upper Jurassic seawater. An important aspect of this study is that the early diagenetic fluids and cement phases of the Upper Jurassic are overprinted by a high-temperature fluid migration or a higher geothermal gradient, with a fluid migration along fault and fracture systems.

Our hypothesis is that the Jurassic seawater (formation water) was diluted from a subsequent infiltration of karst or meteoric water from an unknown source area. The timing of this dilution phase is unclear and might not only have happened during periods of erosion (Figure 14). At nearly every well, the measured Upper Jurassic reservoir fluids became less saline during basin evolution; however, the southwestern area showed a higher salinity than the Jurassic seawater salinity. The least saline fluids from the Upper Jurassic are from the Traunreut well today, which might be caused by a more permeable reservoir. The source area or formation of the high salinity of the diagenetic fluid in the southwestern part is still unclear and could not be determined in this study. Another interesting result is that dolomitization occurred in the same temperature range at the Traunreut well as in the Munich area, but afterward the reservoir temperature must have decreased more strongly in the eastern basin part (Traunreut area) than in the central part (Munich area) of the Molasse Basin. Therefore, the present-day low-temperature anomaly around Lake Chiem might exist since the tectonically active phase, during the Neogene, and the formation of the transparent vein calcites. Further studies should be performed on vein calcite samples from the Traunreut well to understand the fluid evolution, dilution, and change in geothermal gradient in detail and to related tectonic phases. The Geretsried well in the south-central basin part showed two different types of secondary or pseudo-secondary fluid inclusions with the same trapping temperature but varying salinities. In addition, the St. Gallen well indicated an increase in salinity with depth. Those measurements support the theory of a meteoric water influence, migrating from the surface downward. In the outcrop samples, a third calcite cement was found, which probably developed from karstification processes. In the present study, we did not focus on a detailed analysis of the dolomitization process, but it will be addressed in future research.

\section{Data Availability}

The fluid inclusion studies and stable isotope data used to support the findings of this study are available from the corresponding author upon request.

\section{Conflicts of Interest}

The authors declare that they have no conflicts of interest. 


\section{Acknowledgments}

We thank the three anonymous reviewers for suggested comments which significantly improved the final form of this paper. This research was supported by the Federal Ministry of Economic Affairs and Energy on the basis of a decision by the German Bundestag (support code 0324004). The borehole data and rock samples used in this research were kindly provided by ExxonMobil Production Germany GmbH, DEA Deutsche Erdoel AG, St.Galler Stadtwerke, Geothermieprojekt Geretsried Nord GmbH \& Co.KG, Geothermie Unterhaching Produktions-GmbH \& Co. KG, SWM Services GmbH, Geothermische Kraftwerksgesellschaft Traunreut $\mathrm{mbH}$, and Clariant Produkte (Deutschland) $\mathrm{GmbH}$. The hydrochemistry data from the Traunreut well during production was kindly provided by Florian Heine, TUM Chair of Hydrogeology. This work was supported by the German Research Foundation (DFG) and the Technical University of Munich within the funding program Open Access Publishing.

\section{References}

[1] G. H. Bachmann, M. Müller, and K. Weggen, "Evolution of the Molasse Basin (Germany, Switzerland)," Tectonophysics, vol. 137, no. 1-4, pp. 77-92, 1987.

[2] U. Büchi, K. Lemcke, G. Wiener, and J. Zimdars, "Geologische Ergebnisse der Erdölexploration auf das Mesozoikum im Untergrund des schweizerischen Molassebeckens," Bulletin der Schweizerischen Vereinigung von Petroleum-Geologen und-Ingenieuren, vol. 15, pp. 7-38, 1965.

[3] Landesamt für Bergbau, Energie und Geologie - Referat Energieressource Erdöl und Erdgas, Erdöl und Erdgas in der Bundesrepublik Deutschland 2017, Landesamt für Bergbau, Energie und Geologie - Referat Energieressource Erdöl und Erdgas, Hannover, 2018.

[4] J. Véron, "The alpine Molasse Basin: review of petroleum geology and remaining potential," Bulletin für Angewandte Geologie, vol. 10, 2005.

[5] H. Wehner and K. Kuckelkorn, "Zur Herkunft der Erdöle im nördlichen Alpen-/Karpatenvorland,” Erdöl, Erdgas, Kohle, vol. 111, pp. 508-514, 1995.

[6] W. Hiltmann, K. Kuckelkorn, and H. Wehner, "Das Inkohlungsprofil der Bohrung Grambach 1 - erster Hinweis auf eine Olküche im Molassebecken," Erdöl, Erdgas, Kohle, vol. 115, pp. 294-297, 1999.

[7] H. Jacob and K. Kuckelkorn, "Das Inkohlungsprofil der Bohrung Miesbach 1 und seine erdölgeologische Interpretation," Erdöl-Erdgas Z, vol. 93, pp. 115-124, 1977.

[8] R. Schegg, "Thermal maturity of the Swiss Molasse Basin: indications for paleogeothermal anomalies?," Eclogae Geologicae Helvetiae, vol. 85, pp. 745-764, 1992.

[9] R. Teichmüller and M. Teichmüller, "Relations between coalification and palaeogeothermics in Variscan and Alpidic foredeeps of western Europe," in Paleogeothermics: Evaluation of Geothermal Conditions in the Geological Past, G. Buntebarth and L. Stegena, Eds., pp. 53-78, Springer, Berlin, Heidelberg, 1986.

[10] T. Vollmayr, "Temperaturmessungen in Erdölbohrungen der Schweiz," Bulletin der schweizerischen Vereinigung von
Petroleum-Geologen und-Ingenieure, vol. 49, pp. 15-27, 1983.

[11] J. Birner, Hydrogeologisches Modell des Malmaquifers im Süddeutschen Molassebecken, Freie Universität Berlin, Berlin, 2013.

[12] R. Prestel, Untersuchungen zur Diagenese von MalmKarbonatgesteinen und Entwicklung des Malm-Grundwassers im süddeutschen Molassebecken, Stuttgart, Stuttgart, 1990.

[13] I. Stober, Strömungsverhalten in Festgesteinsaquiferen mit Hilfe von Pump-und Injektionsversuchen, Geologisches Jahrbuch, Reihe C, 1986.

[14] R. Prestel, Hydrochemische Untersuchungen im süddeutschen Molassebecken, Bayerisches Landesamt für Wasserwirtschaft, München, Geologisches Landesamt Baden-Württemberg, Freiburg im Breisgau, 1988.

[15] W. Stichler, W. Rauert, S. Weise et al., "Isotopenhydrologische und hydrochemische Untersuchungen zur Erkundung des Fließsystems im Malmkarstaquifer des süddeutschen Alpenvorlandes," Zeitschrift der Deutschen Gesellschaft für Geowissenschaften, vol. 138, pp. 387-398, 1987.

[16] S. Weise, M. Wolf, P. Fritz et al., Isotopenhydrogeologische Untersuchungen im Süddeutschen Molassebecken, Bayerisches Landesamt für Wasserwirtschaft, München, Geologisches Landesamt Baden-Württemberg, Freiburg im Breisgau, 1991.

[17] C. Reinhold, Prozesse, Steuerung und Produkte komplexer Diagenese-Sequenzen in süddeutschen Malm-Karbonaten Die oberjurassische Massenkalk- und Bankkalkfazies bei Geislingen/Steige (Oxford/Kimmeridge, östliche Schwäbische Alb), Technische Universität Berlin, Berlin, 1996.

[18] W. Liedmann, Diagenetische Entwicklung Süddeutscher Malmkarbonate - unter Berücksichtigung lumineszenzpetrographischer, fluid inclusions und geochemischer Untersuchungsmethoden, Dissertation Universität Heidelberg, Heidelberg, 1992.

[19] R. Prestel, M. Wolf, L. Eichinger, and J. Salvamoser, Gaszusammensetzung von Ölfeldwässern und Grundwässern im Malm des süddeutschen Molassebeckens, München, München and Freiburg i. Br., Freiburg im Breisgau, 1991.

[20] B. W. Bertleff, Das Strömungssystem der Grundwässer im Malm-Karst des West-Teils des süddeutschen Molassebeckens, vol. 12, Abhandlungen Geologisches Landesamt Baden-Württemberg, Baden-Württemberg, 1986.

[21] E. Mraz, I. Moeck, M. Wolfgramm, and K. Thuro, Microfacies Analysis in Upper Jurassic Carbonates with Implications for Reservoir Quality in the Molasse Basin, vol. 30, Facies, submitted, 2018.

[22] P. A. Ziegler, Geological Atlas of Western and Central Europe, Shell Internationale Petroleum Mij. and Geol. Soc. of London, 1990.

[23] K. Lemcke, Das Bayerische Alpenvorland vor der Eiszeit: Erdgeschichte, Bau, Bodenschätze, Geologie von Bayern I, Schweizerbart, Stuttgart, 1988.

[24] H. Bachmann and M. Müller, "Die Entwicklung des süddeutschen Molassebeckens seit dem Variszikum: Eine Einführung," Zeitschrift für Geologische Wissenschaften, vol. 24, pp. 3-20, 1996.

[25] J. Kuhlemann and O. Kempf, "Post-Eocene evolution of the North Alpine Foreland Basin and its response to Alpine tectonics," Sedimentary Geology, vol. 152, no. 1-2, pp. 45-78, 2002. 
[26] R. K. F. Meyer and H. Schmidt-Kaler, Paläogeographischer Atlas des süddeutschen Oberjura (Malm), Schweizerbart, Stuttgart, 1989.

[27] B. Niebuhr and T. Pürner, Plattenkalk und FrankendolomitLithostratigraphie der Weißjura-Gruppe der Frankenalb (außeralpiner Oberjura, Bayern), SDGGT, 2014.

[28] K. Beichel, R. Koch, and M. Wolfgramm, "Die Analyse von Spülproben zur Lokalisierung von Zuflusszonen in Geothermiebohrungen," in Beispiel der Bohrungen Gt Unterhaching 1/1a und 2.(Süddeutschland, Molassebecken, Malm), vol. 64, pp. 43-65, Geologische Blätter Nordostbayern, 2014.

[29] E. Lüschen, M. Wolfgramm, T. Fritzer, M. Dussel, R. Thomas, and R. Schulz, "3D seismic survey explores geothermal targets for reservoir characterization at Unterhaching, Munich, Germany," Geothermics, vol. 50, pp. 167-179, 2014.

[30] M. Wolfgramm, J. Bartels, M. Rinke, and T. Jahrfeld, "Der Einfluss von Stratigraphie, Fazies und Diagenese auf die Produktivität im Projekt Kirchstockach," in Geothermiekongress, p. 14, Karlsruhe, Germany, 2011.

[31] O. F. Geyer and M. P. Gwinner, Geologie von Baden-Württemberg, Schweizerbart, Stuttgart, 1991.

[32] H. G. Machel, "Concepts and models of dolomitization: a critical reappraisal," in The Geometry and Petrogenesis of Dolomite Hydrocarbon Reservoirs, C. J. R. Braithwaite, G. Rizzi, and G. Darke, Eds., vol. 235, pp. 7-63, Geological Society, London, 2004, Special Publications.

[33] J. M. Gregg, D. L. Bish, S. E. Kaczmarek, and H. G. Machel, "Mineralogy, nucleation and growth of dolomite in the laboratory and sedimentary environment: a review," Sedimentology, vol. 62, no. 6, pp. 1749-1769, 2015.

[34] E. Hiatt and P. Pufahl, "Cathodoluminescence petrography of carbonate rocks: a review of applications for understanding diagenesis, reservoir quality and pore system evolution," Mineralogical Association of Canada Short Course, vol. 45, pp. 75-96, 2014.

[35] J. Warren, "Dolomite: occurrence, evolution and economically important associations," Earth Science Reviews, vol. 52, no. 13, pp. 1-81, 2000.

[36] M. Wolfgramm, J. Birner, I. Budach et al., Verbundprojekt MAFA: Parametrisierung von Fazies, Diagenese, Strukturund Spannungsfeld sowie Optimierung der Testabläufe im Malm zur Verringerung des Erfolgsrisikos, Teilprojekt A: Sedimentologisch-fazielle Analyse, Testplanung : Forschungsvorhaben 0325673A, 2016.

[37] J. Hoefs, Stable Isotope Geochemistry, Springer, Berlin, Heidelberg, 1997.

[38] A. M. Van den Kerkhof and U. F. Hein, "Fluid inclusion petrography," Lithos, vol. 55, no. 1-4, pp. 27-47, 2001.

[39] T. Driesner, "The system $\mathrm{H} 2 \mathrm{O}-\mathrm{NaCl}$. Part II: correlations for molar volume, enthalpy, and isobaric heat capacity from 0 to $1000^{\circ} \mathrm{C}, 1$ to 5000bar, and 0 to $1 \mathrm{XNaCl}$," Geochimica et Cosmochimica Acta, vol. 71, no. 20, pp. 4902-4919, 2007.

[40] T. Driesner and C. A. Heinrich, "The system H2O-NaCl. Part I: correlation formulae for phase relations in temperaturepressure-composition space from 0 to $1000^{\circ} \mathrm{C}, 0$ to $5000 \mathrm{bar}$, and 0 to $1 \mathrm{XNaCl}$," Geochimica et Cosmochimica Acta, vol. 71, no. 20, pp. 4880-4901, 2007.

[41] R. H. Goldstein and T. J. Reynolds, "Systematics of fluid inclusions in diagenetic minerals," in Society for Sedimentary Geology - SEPM, Tulsa, OK, USA, 1994.
[42] E. Roedder, Fluid Inclusions, Mineralogical Society of America, 1984.

[43] J. Gusterhuber, I. Dunkl, R. Hinsch, H.-G. Linzer, and R. Sachsenhofer, "Neogene uplift and erosion in the Alpine foreland basin (upper Austria and Salzburg)," Geologica Carpathica, vol. 63, no. 4, pp. 295-305, 2012.

[44] M. Mazurek, A. J. Hurford, and W. Leu, "Unravelling the multi-stage burial history of the Swiss Molasse Basin: integration of apatite fission track, vitrinite reflectance and biomarker isomerisation analysis," Basin Research, vol. 18, no. 1, pp. 2750, 2006.

[45] M. Zerlauth, A. Bertrand, G. Rantitsch et al., "Thermal history of the westernmost Eastern Alps (Penninic Rhenodanubian Flysch nappes, Helvetic nappes, and Subalpine Molasse thrust sheets)," International Journal of Earth Sciences, vol. 105, no. 5, pp. 1525-1547, 2016.

[46] J. Mullis, R. F. Mählmann, and M. Wolf, "Fluid inclusion microthermometry to calibrate vitrinite reflectance (between 50 and $270^{\circ} \mathrm{C}$ ), illite Kübler-Index data and the diagenesis/anchizone boundary in the external part of the Central Alps," Applied Clay Science, vol. 143, pp. 307-319, 2017.

[47] N. Beaudoin, N. Bellahsen, O. Lacombe, L. Emmanuel, and J. Pironon, "Crustal-scale fluid flow during the tectonic evolution of the Bighorn Basin (Wyoming, USA)," Basin Research, vol. 26, no. 3, pp. 403-435, 2014.

[48] R. C. Burruss, K. R. Cercone, and P. M. Harris, Timing of Hydrocarbon Migration: Evidenced from Fluid Inclusions in Calcite Cements, Tectonics and Burial History, SEPM Special Publication, 1985.

[49] M. Feely, A. Costanzo, J. Hunt, D. Wilton, and J. Carter, “Oil exploration and its relationship to the world of trapped micron scale fluids: a review of the applications of fluid inclusion microscopy to the study of aqueous and hydrocarbon fluid dynamics in sedimentary basins," in Arctic Technology Conference, Offshore Technology Conference, St. John's, Newfoundland and Labrador, Canada, 2016.

[50] R. H. Goldstein, "Fluid inclusions in sedimentary and diagenetic systems," Lithos, vol. 55, no. 1-4, pp. 159-193, 2001.

[51] R. K. McLimans, "The application of fluid inclusions to migration of oil and diagenesis in petroleum reservoirs," Applied Geochemistry, vol. 2, no. 5-6, pp. 585-603, 1987.

[52] J. Parnell, "Potential of palaeofluid analysis for understanding oil charge history," Geofluids, vol. 10, 82 pages, 2010.

[53] T. Agemar, R. Schellschmidt, and R. Schulz, "Subsurface temperature distribution in Germany," Geothermics, vol. 44, pp. 65-77, 2012.

[54] J. R. Allan and W. Wiggins, Dolomite Reservoirs: Geochemical Techniques for Evaluating Origin and Distribution, AAPG, 1993.

[55] C. Mayrhofer, R. Niessner, and T. Baumann, "Hydrochemistry and hydrogen sulfide generating processes in the Malm aquifer, Bavarian Molasse Basin, Germany," Hydrogeology Journal, vol. 22, no. 1, pp. 151-162, 2014.

[56] I. Stober, "Hydrochemical properties of deep carbonate aquifers in the SW German Molasse basin," Geothermal Energy, vol. 2, p. 1, 2014.

[57] H. Waber, M. Heidinger, G. Lorenz, and D. Traber, Hydrochemie und Isotopenhydrogeologie von Tiefengrundwässern in der Nordschweiz und im angrenzenden Süddeutschland, Nationale Genossenschaft für die Lagerung radioaktiver Abfälle, 2014. 
[58] I. Stober, M. Wolfgramm, and J. Birner, Hydrochemie der Tiefenwässer in Deutschland, vol. 41, no. 42, 2013, Zeitschrift für Geologische Wissenschaften, Berlin, 2013.

[59] J. Birner, C. Mayr, L. Thomas, M. Schneider, T. Baumann, and A. Winkler, "Hydrochemie und Genese der tiefen Grundwässer des Malmaquifers im bayerischen Teil des süddeutschen Molassebeckens [hydrochemistry and evolution of deep groundwaters in the Malm aquifer in the Bavarian part of the south German Molasse Basin]," Zeitschrift für Geologische Wissenschaften, vol. 39, pp. 291-308, 2011.

[60] M. Wolfgramm, T. Bloch, J. Bartels et al., "Reservoir-geological characterization of a fractured limestone: results obtained from the geothermal well St. Gallen GT-1 (Switzerland)," in Proceedings of the World Geothermal Congress, Melbourne, Australia, 2015.

[61] M. Wolfgramm, H.-D. Voigt, and J. Bartels, "Geothermieprojekt St. Gallen, Test und Stimulation,” Abschlussbericht, 2013.

[62] T. Agemar, J.-A. Alten, B. Ganz et al., "The geothermal information system for Germany-GeotIS," Zeitschrift der Deutschen Gesellschaft für Geowissenschaften, vol. 165, no. 2, pp. 129-144, 2014.

[63] M. Schneider, L. Thomas, J. Birner et al., Wissenschaftliche und technische Grundlagen zur strukturgeologischen und hydrogeologischen Charakterisierung tiefer geothermisch genutzter Grundwasserleiter am Beispiel des süddeutschen Molassebeckens, Endbericht - BMU Forschungsvorhaben, 2012.

[64] I. Friedman and J. R. O'Neil, Data of Geochemistry: Compilation of Stable Isotope Fractionation Factors of Geochemical Interest, US Government Printing Office, 1977.

[65] S.-T. Kim and J. R. O'Neil, "Equilibrium and nonequilibrium oxygen isotope effects in synthetic carbonates," Geochimica et Cosmochimica Acta, vol. 61, no. 16, pp. 3461-3475, 1997.

[66] K. Wallmann, "The geological water cycle and the evolution of marine $\delta 18$ O values," Geochimica et Cosmochimica Acta, vol. 65, no. 15, pp. 2469-2485, 2001.

[67] P. Fritz and D. G. W. Smith, "The isotopic composition of secondary dolomites," Geochimica et Cosmochimica Acta, vol. 34, no. 11, pp. 1161-1173, 1970.

[68] M. Wolfgramm, C. Buse, E. Mraz, and S. Thiem, Analyse von Bohrklein: Methode sowie Cuttingatlas für Karbonate des Oberjura im Molassebecken, German Geothermal Congress, Munich, 2017.

[69] J. D. Marshall, "Climatic and oceanographic isotopic signals from the carbonate rock record and their preservation," Geological Magazine, vol. 129, no. 2, p. 143, 1992.

[70] M. Wolfgramm, M. Dussel, E. Lüschen, R. Schulz, R. Thomas, and R. Koch, "Zuflusszonen im Malm-Untersuchungen des geothermischen Hauptgrundwasserleiters im süddeutschen Molassebecken," BBR - Sonderheft Geothermie, vol. 62, pp. 75-82, 2012.

[71] J. D. Hudson, "Stable isotopes and limestone lithification," Journal of the Geological Society, vol. 133, no. 6, pp. 637-660, 1977.

[72] K. Lemcke, "Übertiefe Grundwässer im süddeutschen Alpenvorland," Bulletin der Schweizerischen Vereinigung von Petroleum-Geologen und-Ingenieuren, vol. 42, pp. 9-18, 1976.

[73] K. W. Barthel, "Die obertithonische, regressive FlachwasserPhase der Neuburger Folge in Bayern," Abhandlungen, vol. 142, p. 172, 1969.

[74] R. J. Bakker, "Clathrates: computer programs to calculate fluid inclusion V-X properties using clathrate melting temperatures," Computational Geosciences, vol. 23, no. 1, pp. 1-18, 1997.

[75] J. Tóth, "Hydraulic continuity in large sedimentary basins," Hydrogeology Journal, vol. 3, no. 4, pp. 4-16, 1995.

[76] C. E. Barker and R. H. Goldstein, "Fluid-inclusion technique for determining maximum temperature in calcite and its comparison to the vitrinite reflectance geothermometer," Geology, vol. 18, no. 10, pp. 1003-1006, 1990.

[77] R. H. Goldstein, "Reequilibration of fluid inclusions in lowtemperature calcium-carbonate cement," Geology, vol. 14, no. 9, pp. 792-795, 1986.

[78] E. Mraz, I. Moeck, S. Bissmann, and S. Hild, "Multiphase fossil normal faults as geothermal exploration targets in the Western Bavarian Molasse Basin: case study Mauerstetten," Zeitschrift der Deutschen Gesellschaft für Geowissenschaften, vol. 169, no. 3, pp. 389-411, 2018.

[79] J.-P. Wrobel, T. Fritzer, C. Mikulla, D. Schuldes, and A. Suckow, "Forschungsbohrung Altdorf bei Landshut/Niederbayern-Erkundung einer geothermischen Anomalie im Bereich des Landshut-Neuöttinger-Hochs," Grundwasser, vol. 7, no. 1, pp. 14-24, 2002.

[80] M. Selg and P. Wagenplast, Beckenarchitektur im süddeutschen Weißen Jura und die Bildung der Schwammriffe, vol. 32, Jahreshefte des Geologischen Landesamtes Baden-Wuerttemberg, Baden-Württemberg, 1990. 

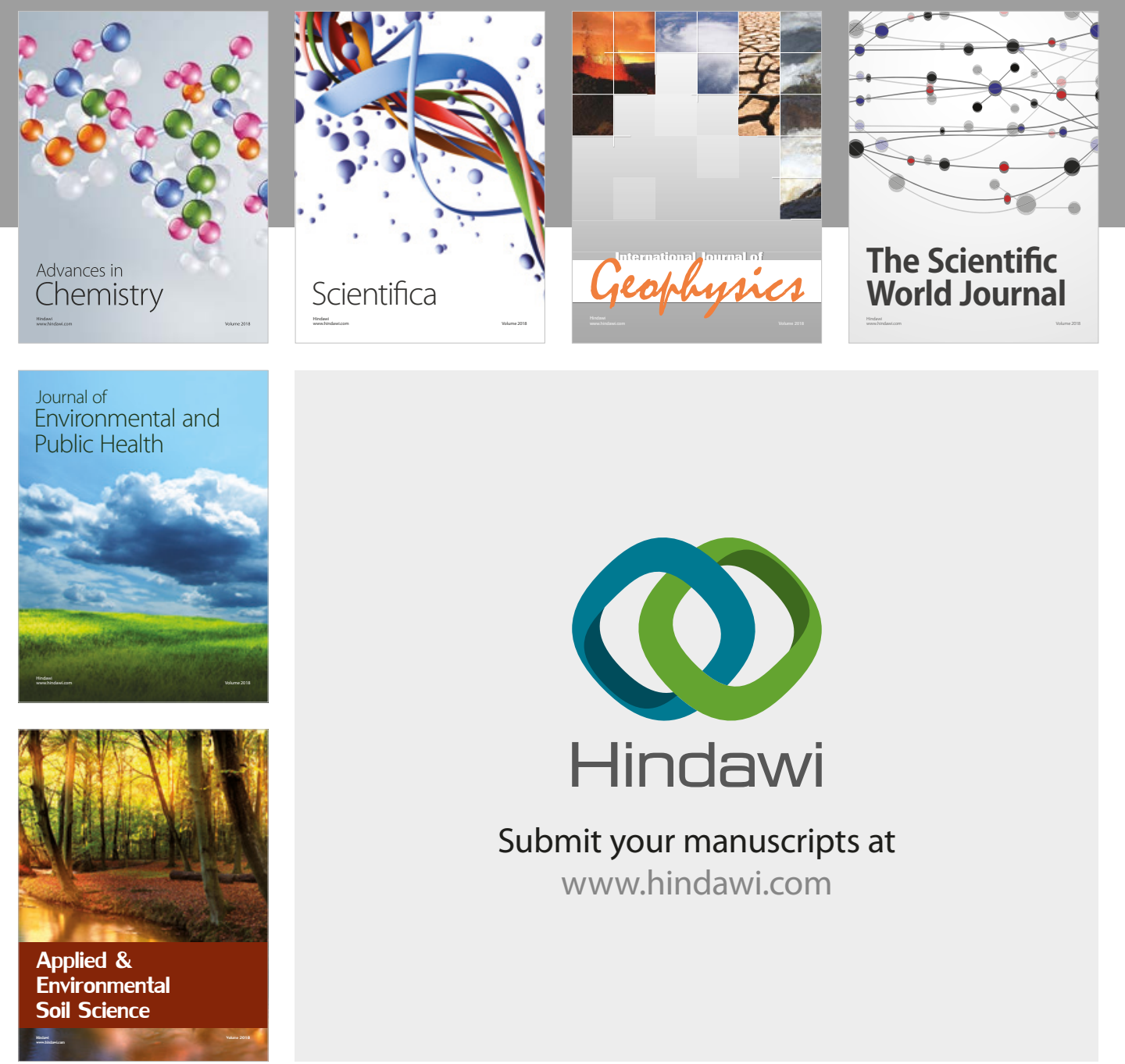

The Scientific

\section{World Journal}
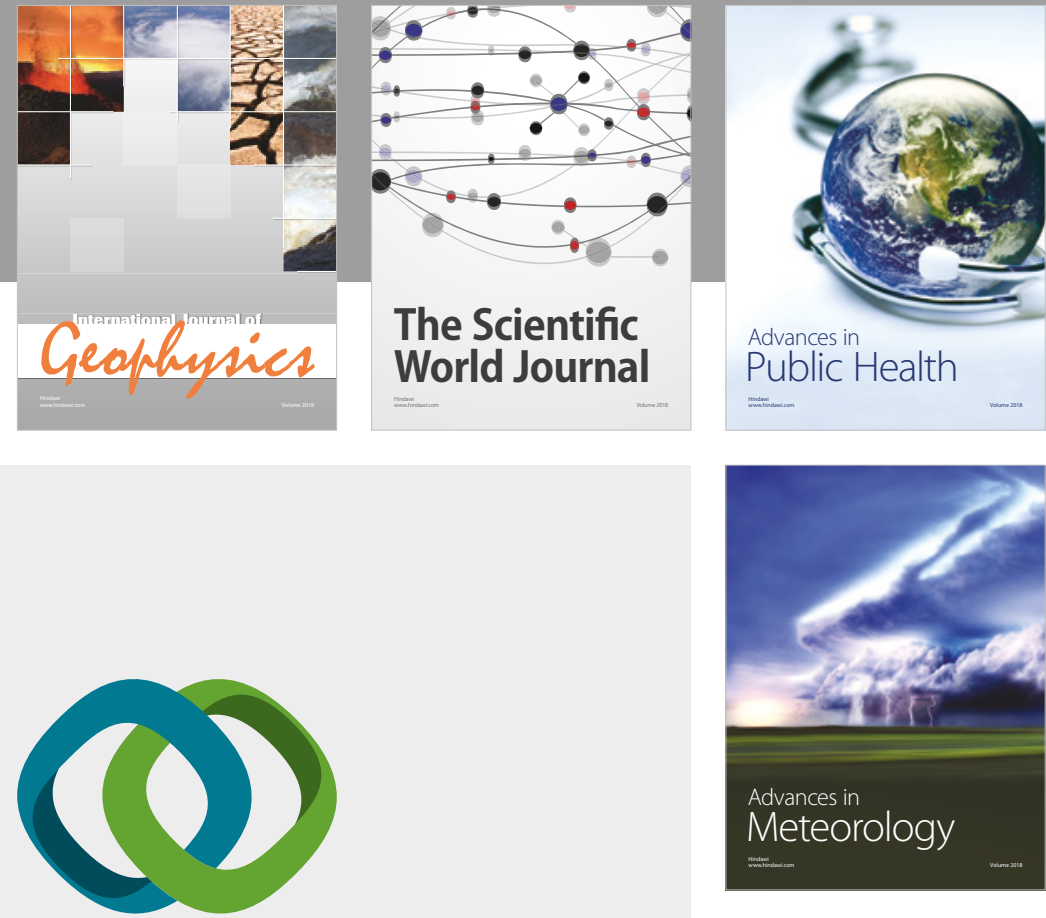

Advan

Public Health

\section{Hindawi}

Submit your manuscripts at

www.hindawi.com
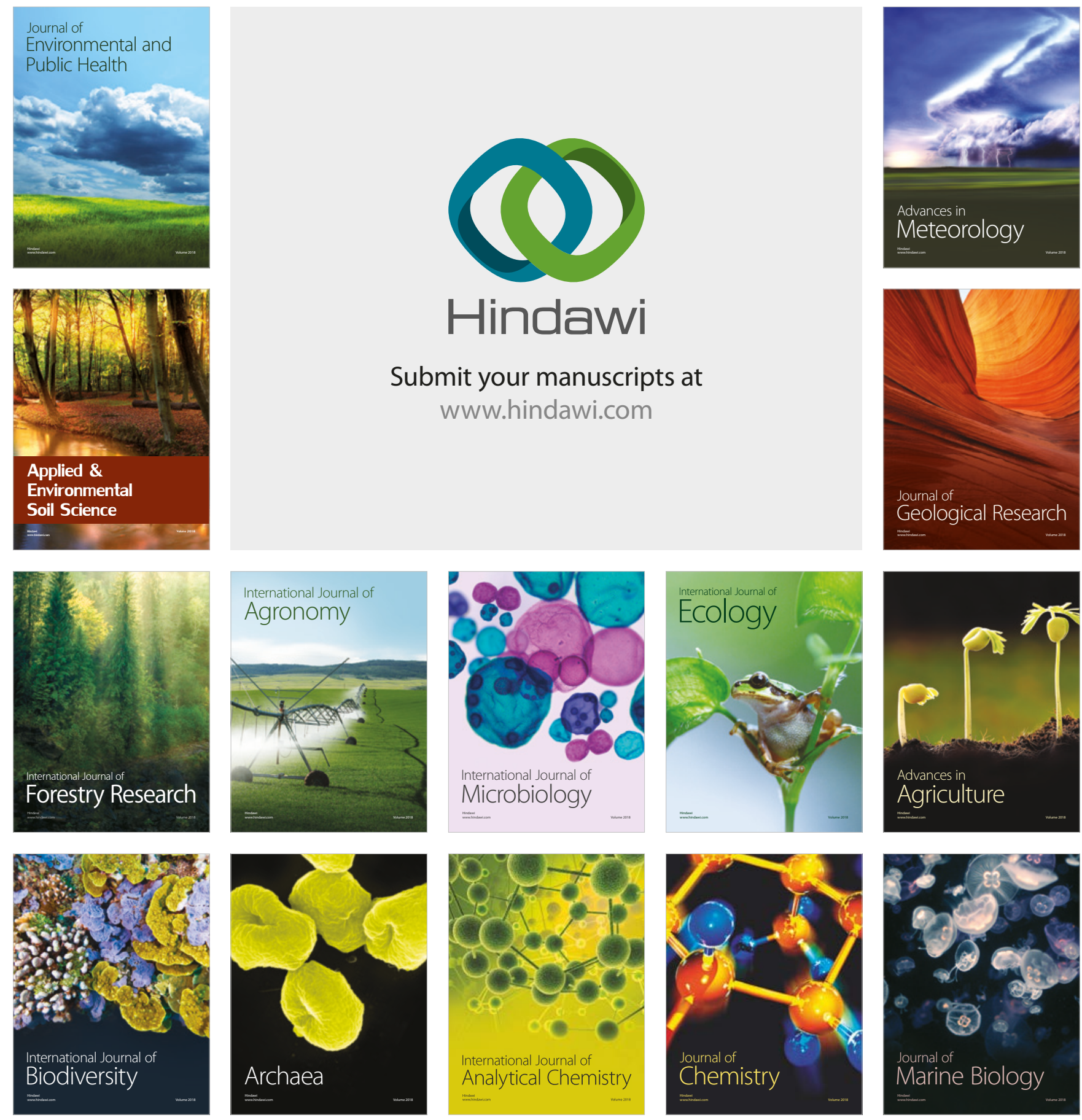